\title{
The Stoic Seneca on virtus, gaudium and voluptas ${ }^{1}$
}

\section{Introduction}

1.1. Anyone who is familiar with classical antiquity, knows that the Stoa considered virtus (Gr. aretê) to be the supreme good (summum bonum), i.e. that in which happiness resides, ${ }^{2}$ whereas in Epicurus' opinion voluptas (Gr. hêdonê; pleasure) was the supreme good. In this paper, I will explore how much room there was for pleasure and joy (gaudium, Gr. chara, see infra) within Greco-Roman Stoicism despite the absolute primacy of virtus and despite the notorious fight the Stoa put up with pleasure. ${ }^{3}$

Besides The Hellenistic Philosophers by A.A. Long-D. Sedley (infra LS) (1987) and several studies on Stoic ethics, I have especially made use of the lemma voluptas in the Lessico morale di Seneca by Antonella Borgo (1998) and of the study "“Pflicht' und 'Lust' in der Ethik der alten Stoa" by Woldemar Görler (1984). Borgo is not only useful for the heuristics, but also offers a first tentative interpretation and systematization of the material. ${ }^{4}$ Görler's main thesis is that whereas proficientes performing kathekonta might not possess the wise man's stable chara/gaudium, they already experience moments of chara/gaudium, a kind of pleasure or joy the Stoa did not have a specific technical term for.

We know that Cleanthes and Chrysippus, who belong to the Old Stoa, both wrote a work called "Peri hêdonês". ${ }^{5}$ However, as is well known, only fragments survive of the Greek Stoa (see Stoicorum Veterum Fragmenta, infra SVF). LS offer a chapter on "Pleasure" in the Epicurean school, but only mention "pleasure" in the Stoa in passing, namely under the item "Passions". 6

In this paper, I will concentrate on the position of the Roman Seneca, analyzing what this Stoic wrote in his philosophical works on the relative position of

1 My colleague Geert Roskam (KU Leuven) proofread both an early and the penultimate version of this text. His comments and suggestions, together with our conversations, played a crucial part in the development of this study. I also thank my colleague Tom Deneire (Huygens ING / KU Leuven) for his skillful and conscientious help with the English redaction of my text.

2 Cp. for this expression e.g. vit. 16, 1: in virtute posita est vera felicitas.

3 In epist. 88, 5 Seneca characterizes the Stoic as virtutem solam probantem et voluptates refugientem! In epist. 51, 6 we read: debellandae sunt in primis voluptates, quae.. saeva quoque ad se ingenia rapuerunt, and in 51,13 voluptates praecipue exturba et invisissimas habe!

4 Borgo not only lacks a lemma gaudium, she also falls short where gaudium is discussed under the lemma voluptas. For instance, in the paragraphs on Seneca's vocabulary regarding gaudium there is no reference to epist. 59, 2 .

5 Diogenes LaerTiUs VII, 103 and 175.

6 Rist, on the other hand, does offer a chapter on "Problems of pleasure and pain" in his well-known work on the Stoa, 1969, p. 37-53. 
virtus and voluptas. In doing so, I will also discuss gaudium, also known as vera voluptas or true pleasure, as viewed by the Stoa in general and Seneca in particular.

We need to realise that Seneca is a Stoic who regularly mentions Epicurus and voluptas. ${ }^{7}$ In this way, it seems that Seneca leaves a little more room for pleasures and joy than his Stoic predecessors. ${ }^{8}$ However, since more often than not Seneca interprets the term voluptas as physical and sensuous pleasure, ${ }^{9}$ the Roman very often talks about pleasure in a negative way, namely as a passion or adfectus (Gr. pathos), a thing well known to Seneca's readers. Besides, like his Stoic predecessors, Seneca wants to avoid paying too much attention to acceptable pleasure. ${ }^{10}$ Still, the focus of this study is precisely the room Seneca leaves for voluptas and gaudium. Apart from Seneca, I have also paid special attention, whenever it seemed useful, to the information and expressions that Cicero offers with regards to Stoicism and Epicureanism.

1.2. Seneca discussed the relationship between virtus and voluptas in depth in one of his so-called dialogues, namely De vita beata (infra: vit.) $6^{11}-16$. In these chapters, the philosopher first of all contests Epicurus' opinion and that of the hedonists. In the previous chapters, gaudium is dealt with, and in the next part of the dialogue the indifferentia are discussed, both themes that are also of importance for our study. ${ }^{12}$ Besides vit., I have also brought together other passages in which Seneca offers his opinion on gaudium and voluptas, such as De beneficiis (infra: ben.) IV, 2, 1-4 (about the erroneous link between virtus and voluptas in Epicureanism); IV, 13, 12 (Epicurean pleasure vs. Stoic "pleasure") and VII, 2, 1-4 (about true and false pleasure); epist. 18, 9-10 (about the moderate pleasure that Epicurus promoted); 21, 9b-11 (about Epicurus' moderate pleasure and different kinds of desire and pleasure); 59, 1-4 (about the terms gaudium and voluptas) and 59, 14-18 (gaudium vs. voluptas; praise of gaudium) and the letters 23 (about true joy) and 92 (Stoicism vs. Epicureanism). ${ }^{13}$

1.3. At this point, it seems useful to make a first note on Seneca's terminology and definitions. As a result of using the word voluptas in epist. 59, 1 to denote the

7 BORGO (1998), p. 202, counts 337 instances of voluptas in Seneca.

8 See MaURACH (2000), p. 118, n. 126; cp. also p. 119: Seneca takes a less strict position when it comes to preferable indifferentia.

9 As BORGo (1998), p. 198 states correctly.

10 Cp. Görler (1984), p. 399, n. 6 and InWOOD (1999), p. 693.

11 Seneca prepares this part of his text with 5, 4: Nam quod ad voluptatem pertinet.

12 As in vit. 6-16, virtus and voluptas are also opposed in book II of Cicero's fin., where he criticizes the Epicureanism presented in book I. See e.g. fin. II, 44.

13 For the heuristics we have used the Concordantiae Senecanae, for instance s.v. gaudium, indifferentia, titillatio and voluptas; also Мотто (1970), s.v. "Joy", and s.v. "Pleasure" (cp. also Мотто 2001), and especially BorGo (1998), for instance s.v. adfectus, libido, luxuria, morbus, voluptas. For the study of vit., KUEN (1994) is available. For the study of the Stoic tradition, SVF s.v. chara and hêdonê, LS, HAYNES (1962), Rist (1969), p. 37-53 (criticizing Haynes), GOSLING - TAYLOR (1982), and especially GöRLER (1984) are useful. To boot, Haynes, Rist and Görler mention Seneca several times. 
pleasure he took in reading a recently received letter from Lucilius, Seneca pauses in epist. 59, $1-4^{14}$ to consider the usage of the terms voluptas and gaudium. He points at both the common meaning of these words $(59,1$ verbis publicis; 59, 2 vulgo) and their more specific, technical meaning in Stoic philosophy $(59,1$ significationem Stoicam; 59, 2 nostrum album).

In common Latin (and in Seneca, for that matter), voluptas can denote all kinds of pleasure or delight (e.g. 59, 1 animi hilarem adfectionem). However, as a technical term in Stoic philosophy, according to Seneca voluptas more specifically points at an adfectus, or "a passion" (Gr. pathos) (epist. 59, 4), a vitium (59, 1; cp. ben. IV, 11, 5), a rem infamem $(59,2)$. Seneca defines this pleasure in 59,4 as opinione falsi boni motam, inmoderatam et inmodicam - "it is inspired by an erroneous opinion concerning a false good; it exceeds control and is unrestrained." This is Seneca's interpretation of the definition of the pathos hêdonê as alogos eparsis, "an elation of the soul disobedient to reason" (trans. B. Inwood). In this negative sense, voluptas first of all refers to sensual pleasure and self-indulgence. However, often the word voluptas also has a negative connotation when Seneca is not explicitly discussing pathos. Wallowing in pleasure or seeking out pleasure is also called luxuria by Seneca, which is an unmistakably negative term (cf. vit. 11, 4 and 13, 2; epist. 59, 18 and 116, 3; and Marc. 23, 3).

Virtuous conduct brings about a certain joy (epist. 59, 1-4), which Seneca sometimes calls voluptas too (e.g. vit. 9, 1-2; cp. epist. 18, 10). Elsewhere, he (polemically) refers to this joy as vera voluptas (vit. 4,2$).{ }^{15}$ Yet, Seneca's technical term for the joy connected with virtuous conduct is gaudium (Gr. chara; epist. 59, 2 and 14 sq.; vit. 4, 5). Alternatively, he also uses laetitia for this joy (cf. vit. 4, 4; 15, 2 and 22, 3; cp. epist. 72, 8). ${ }^{16}$ Seneca defines gaudium in 59, 2 as animi elatio suis bonis verisque fidentis, "joy is an elation of the soul -a soul that trusts in the goodness and truth of its own possessions", which is his interpretation of the definition of chara as eulogos eparsis - "a rationally justifiable uplift (in the soul)" (cp. B. Inwood).

Reproachable voluptates are called falsa gaudia in epist. 59, 18. The opposition gaudium - voluptas (e.g. vit. 3, 4 and epist. 59, 14-18) is already present in Chrysippus, namely as chara - hêdonê. ${ }^{17}$

14 Cp. Borgo (1998), p. 200.

15 Or as solida voluptas (Helv. 5, 5). Cp. ben. VII, 2, 3-4. In epist. 122, 6 vera voluptas refers to something else.

16 Seneca uses laetitia differently than Cicero, see also notes 17 and 18 infra. The article "laetitia" of the Thesaurus Linguae Latinae, vol. VII.2.2. (1979), col. 875, does not at all acknowledge this difference in doctrinis philosophorum.

17 See Görler (1984), p. 400. Cp. also CICERO, Tusc. IV, 13: nam cum ratione animus movetur placide atque constanter, tum illud gaudium dicitur; cum autem inaniter et effuse animus exultat, tum illa laetitia gestiens vel nimia dici potest, quam ita definiunt: sine ratione animi elationem. Cicero uses laetitia gestiens where Seneca uses voluptas or luxuria. See also note 18 infra. Chrysippus sometimes used hêdonê in a positive sense, according to GöRLER (1982), p. 399, n. 6, who refers to DiOGENES LAERTIUS VII, 103. Compare this practice with the fact that he sometimes spoke of "something good" when he meant a preferable indifferent 
In his philosophical works, Seneca has used voluptas and gaudium both in the technical and in a more general sense. As can be expected, one finds the technical, Stoic meaning especially where the opposition voluptas - gaudium is being discussed in depth. ${ }^{18}$

1.4. Before continuing, I wish to stress the fundamental nature of the differences between what Epicurus and the Stoa taught regarding virtus and voluptas. ${ }^{19}$ There is more to the matter than the well-known fact that the Stoa saw virtus as the supreme good and Epicurus saw voluptas as the supreme good.

For Epicurus, pleasure is a matter of central concern, while in the Stoa pleasure is mostly considered in the context of the struggle against the passions. For Epicurus, pleasure is a feeling that every living creature seeks by nature as the supreme good. Pleasure presents itself to the senses as a thing that is evidently good. ${ }^{20}$ Every pleasure is a good thing an sich, although reason does teach that it is not wise to pursue each and every pleasure.

In their polemical discussion with the Epicureans, the Stoics state that every living creature initially seeks self-preservation (conciliatio; Gr. oikeiosis) and that pleasure, Gr. hêdonê, is (only) a by-product (Gr. epigennema) of actions that realise such self-preservation. Pleasure that exceeds the boundaries defined by nature is or is caused by an erroneous judgment, and is a bad thing (hêdonê s.s.; pathos). The joy that comes from practicing virtue is or is caused by a correct judgment, and is a good thing (chara, one of the eupatheiai). In this way, pathos and chara are opposed to each other as alogos and eulogos eparsis. ${ }^{21}$

thing, see Forschner (1981), p. 171-172 and note 76. See also Plutarch, Stoic. rep. 1048a and INWOOD (1999), p. 693. For the terminology of the classic Stoa, see GÖRLER (1984).

18 For the terminology of Cicero, see Kilb (1939), Grimal (1978), p. 34-41 and also BorGo (1998). In Tusc. IV, 66 Cicero writes that he has distinguished gaudium and laetitia in view of his own didactic intentions: he uses gaudium for joy and laetitia (gestiens) for exaggerated joy; see also fin. III, 1 ; III, 35 ; and Tusc. III, 23 (see ThlL s.v. laetitia and KILB 1939). In the case of Seneca, GRIMAL (1978), p. 332 erroneously opposes laetitia instead of voluptas (hêdonê) to gaudium (chara). For gaudium as joy connected to virtus, see e.g. CiCERO, fin. V, 69. In Cicero perturbatio animi is the usual expression for pathos (see especially fin. III, 35), in Seneca the term used for pathos is adfectus (see especially ira II, 3, 1 and epist. 75, 1012). In epist. 75, 10-12 Seneca describes the difference between adfectus and morbus, see BORGO (1998), s.v. adfectus, p. 15.

19 According to Seneca, Stoicism and Epicureanism are opposed to each other on three essential points: regarding the supreme good, a thing discussed in our paper (virtus vs. voluptas), regarding the divine (a central role for the deity $v s$. no interference of the gods in human affairs), and regarding social and political engagement (engagement $v s$. no participation in political affairs). For Seneca succinctly on Epicureanism, see epist. 90, 35: Non de ea philosophia loquor quae civem extra patriam posuit, extra mundum deos, quae virtutem donavit voluptati.

20 See CiCERo, fin. I, 30.

21 The thesis that pathos and chara are an erroneous and correct judgment respectively, or the result of an erroneous c.q. correct judgment, is tied up with the Stoa's monistic perspective on the human soul. Some Stoics (e.g. Chrysippus) have stated that pleasure is a judgment, 
According to Epicurus, the senses determine that voluptas is the supreme good, while for the Stoa knowledge of the supreme good is always a matter of the animus. ${ }^{22}$ Seneca offers his opinion on this issue in epist. 124, 2: Quicumque voluptatem in summo ponunt sensibile iudicant bonum, nos contra intellegibile, qui illud animo damus. $^{23}$

\section{Seneca on Epicurus' teachings about pleasure}

2.1. In the following part of this study, I want to point out what Seneca wrote about Epicurus' teachings regarding the supreme good and how he criticized the Greek philosopher. In Seneca's epist. 18, 9 Epicurus is called ille magister voluptatis, and in epist. 92, 25 Epicureanism is dubbed ipsa officina voluptatis!

In vit. 6-16 Seneca presents Epicurus' position through the interventions of a fictitious opponent and his own reactions. However, as previously announced, I will also include other passages from Seneca's philosophical works in this discussion and other parts of my study.

2.2. According to Seneca, epist. 21, 10, the entrance of Epicurus' gardens featured a sign that said: Hospes, hic bene manebis, hic summum bonum voluptas est. Moreover, in epist. 99, 28 Seneca says to Epicureans: Unum bonum nostis, voluptatem, unum malum, dolorem. We need to realise that Epicurus thought of hêdonê (voluptas) in the broad sense of the word. The fact that he called pleasure the supreme good ties in with his view on human nature. In his view, we know from experience that from birth every living creature seeks pleasure (and wishes to be free of pain).

I immediately add to the previous point that for Epicurus moral excellence, especially prudentia (Gr. phronêsis), "prudence, wisdom", along with practicing the other cardinal virtues, was indispensable to attain pleasure. ${ }^{24}$ In vit. 7,1 we read: Itaque negant posse voluptatem a virtute diduci et aiunt nec honeste quemquam vivere ut non iucunde vivat, nec iucunde ut non honeste quoque (cp. vit. 10, 1 and $15,1) .{ }^{25}$ Indeed, ben. IV, 2, 1 is quite clear about Epicurus' teachings: non est voluptas sine virtute (see also epist. 85, 18 infra sub 3.2).

All things considered, the pleasure that Epicurus himself envisaged, was, as Seneca has regularly pointed out (e.g. vit. 13, 1), a moderate pleasure, tailored to what nature needs, which is, both in Epicurus' and Seneca's opinion, not much. We can

others (e.g. Zeno) that it is the result of a judgment. See GosLING - TAYLOR (1982), p. 419 and p. 423, and also FORSCHNER (1981), p. 138. Seneca claims that pleasure is based on a judgment (see e.g. epist. 59, 4).

22 Cp. e.g. CicERo, fin. I, 30; II, 36; II, 91; III, 3, and also BRENNAN (2003), p. 277.

23 Cp. Inwood (2007), ad Sen. epist. 124, 2-6 (p. 364-368). Cp. also vit. 2, 2: animi bonum animus inveniat, and epist. 66, 35: Ratio ergo arbitra est bonorum ac malorum.

24 EPICURUS, Ad Menoeceum (infra: Men.) 132.

25 EpICURUS, ibid.; cp. Kyriai doxai (infra: KD) 5. Compare Seneca's expression to Cicero's in Tusc. V, 26: negat quemquam iucunde posse vivere, nisi idem honeste, sapienter iusteque vivat. Cp. e.g. also fin. I, 57 and II, 51. 
gather this much from the discussion of several quotes from Epicurus ("extras") that Seneca uses to finish off epist. 2-29; ${ }^{26}$ see e.g. 2, 5; 4, 10 magnae divitiae sunt lege naturae composita paupertas; 18, 9-10;21, 10;27, 9. Epicurus considers moderation and frugalitas necessary things; more generally speaking, he advocates a rational, calculating attitude towards pleasure. ${ }^{27}$

Not all pleasure is equally desirable; hence the necessity to make rational choices and to distinguish between different kinds of enjoyments.

(1) In his presentation of Epicureanism and his criticism on the school (books I and II of De finibus bonorum et malorum respectively; infra: fin.), Cicero deals at great length with the fact that in Epicurus' opinion hêdonê or voluptas did not only involve pleasure in the common sense of the word, but also the absence of pain (fin. I, 37 etc.). According to Cicero and Diogenes Laertius, whose views are usually taken over in modern manuals, Epicurus supposedly distinguished between kinetic and static or katastematic ${ }^{28}$ pleasure. $^{29}$ Pleasure in the common sense of the word is, according to Cicero, a pleasure residing in motu -it is "kinetic", while the other pleasure is one residing in stabilitate - it is "static". ${ }^{30}$ Static pleasure amounts to the absence of pain, in particular the absence of hunger, thirst and cold. Kinetic pleasure can be defined as pleasure involving active stimulation, for instance the pleasure experienced in food or drink, or sexual intercourse. Kinetic enjoyments (and sensuous enjoyments in particular) are more powerful than static pleasure, but last less long, and the desire for them involves a bigger dependency on Fortuna than static pleasure, which is therefore deemed preferable by Epicurus. ${ }^{31}$

In epist. 18, 9-10 Seneca praises Epicurus for staying out of Fortuna's reach by choosing for moderate pleasure, namely the absence of hunger and thirst. In vit. 7, 4 Seneca only discusses pleasure residing in motu, "in movement", stating that it is not a stable good. Without any doubt, Seneca is targeting pleasure in the common

${ }^{26}$ In the "extras" of epist. 2-29 Seneca regularly cites Epicurus to underscore his own positions.

27 See EpICURUS, Men. 129-130. Cp. CiCERo, fin. I, 32: ratione voluptatem sequi, and SENECA, De otio 7, 2: nec ille tertius, de quo male existimare consensimus, voluptatem inertem probat sed eam quam ratione efficit firmam sibi.

28 In Greek "katastematikos", i.e. "in rest".

29 One can read about this distinction of Epicurus, for instance, in BRUNSCHWIG - SEDLEY (2003), p. 161. Several studies refer to DiOgenES LAERTIUS X, 136, and also to CiCERO, fin. II, 9. Cicero, according to STOKES (1995), p. 145, is our clearest source for this distinction. NIKOLSKY (2001), however, contends that the distinction in question was only later ascribed to Epicurus. STOKES (1995) has also studied what Epicurus and Cicero wrote in this respect; he is convinced that Epicurus himself must have made the distinction katastematic -kinetic (see e.g. p. 159). Still, NiKOLSKY (2001) did not use STOKES (1995) for his study.

30 For the terminology, cp. e.g. CICERO, fin. II, 6; II, 9: restincta enim sitis stabilitatem voluptatis habet, illa autem voluptas ipsius restinctionis in motu est; fin. II, 16: in motu vs. in stabilitate, or also fin. II, 75 and 77.

31 LS vol. 1, p. 123. For Epicurus' preference for static pleasure, cp. CICERO, e.g. fin. I, 38 and II, 10. In Tusc. III, 47 Cicero wrote regarding Epicurus: summamque esse voluptatem nihil dolere. 
sense of the word here. ${ }^{32}$ The reason that Seneca, unlike Cicero, only speaks of pleasure in this sense here, is probably the fact that in opposing voluptas and virtus he is mainly concerned with pleasure in the common sense of the word. Also mentioning pleasure as the absence of pain in the polemical discussion in vit. would unnecessarily complicate and weaken his (relatively short) argument.

(2) $\mathrm{We} \mathrm{know}^{33}$ that Epicurus made a second distinction between three different kinds of pleasure: enjoyments that are natural and necessary, in particular food and drink; enjoyments that are natural but not necessary, e.g. sexual intercourse; and enjoyments that are neither natural nor necessary, e.g. a statue, which produces glory. The last kind consists of hollow, worthless enjoyments. The philosopher is content with pleasures that are natural and necessary, which for that matter can be obtained without much difficulty.

This distinction is partly found in Seneca's epist. 21, 9b-11. According to Seneca, Epicurus does not ingest food to stimulate his senses, but to alleviate his hunger, for he is content with naturali et gratuito remedio ( $\$ 10)$. In hac voluptate consenui, as Epicurus once put it. Seneca clarifies this kind of enjoyment (in hac voluptate) in the following manner: De his tecum desideriis loquor quae consolationem non recipiunt, quibus dandum est aliquid ut desinant $(\S 11)$. In this case, (natural and necessary) needs are at stake that cannot be ignored and therefore should be attended to in order to stop them. The final part of $\$ 11$ also deals with such needs; the belly cannot be ignored, but can be content with little, or, one has to give the belly what it needs, not what one can give. The sentence de his... desideriis is followed by Nam de illis (sc. desideriis) extraordinariis quae licet differre, licet castigare et opprimere, hoc unum commonefaciam: ista voluptas naturalis est, non necessaria. ${ }^{34}$

In epist. 4, 10 we learn that, according to Epicurus, the only thing nature demands is non esurire, non sitire, non algere. And to this he adds: parabile est quod natura desiderat et adpositum, ${ }^{35} \mathrm{cp}$. gratuito in epist. $21,10$.

(3) Finally, Epicurus also distinguished between spiritual and physical enjoyments, ${ }^{36}$ preferring the former over the latter, not only because the mind allows us to relive enjoyments from the past when experiencing less pleasurable moments ${ }^{37}$ and to consider the possible enjoyments in the future, but also because there is great pleasure in (rationally) conquering our fear of death and of the gods. ${ }^{38}$ In vit. 6, 1 Seneca

32 See Grimal (1969), ad loc. That this was the common meaning of the word voluptas can be gathered, for instance, from CICERO, fin. II, 8: Omnes enim iucundum motum, quo sensus hilaretur, Graece hêdonên, Latine voluptatem vocant. See also fin. II, 28 and II, 77.

33 See Epicurus, Men. 127 and KD 29; also Cicero, fin. I, 45; II, 26 and Tusc. V, 93.

34 In contrast with Cicero (fin. II, 26), Seneca did not criticize this classification of the pleasures.

35 See EPICURUS, Men. 130. Parabilis is also used with regards to natural and necessary enjoyments in CiCERO, Tusc. V, 93 and with regards to natural riches in fin. II, 91.

36 Cp. Diogenes Laertius X, 136.

37 For instance, in Diogenes LAertius X, 22 we hear that on his deathbed Epicurus still fully enjoyed the philosophical conversations he had previously had with Idomeneus.

38 See Epicurus, Men. 131. Cp. Cicero, fin. I, 40-41. 
mentions that the Epicurean's spiritual enjoyments consist in the memory of past physical pleasure and the prospect of future physical pleasure. ${ }^{39}$ Yet whichever way you look at it, Seneca narrows down the meaning of spiritual pleasure for Epicurus here.

The absence of physical pain and of the disturbance of peace of mind (in particular fear) (ataraxia), which are essentially two kinds of static or katastematic pleasure, are the highest pleasures for Epicurus ${ }^{40}$ (corpus sine dolore... animus sine perturbatione [Seneca, epist. 66, 45]; cp. 66, 47: corporis quietem ab omni incommodo liberam et animi remissionem bonorum suorum contemplatione gaudentis.) $)^{41}$

2.3. In epist. 124, 6 sq. Seneca criticizes the fact that Epicurus entirely bases his ideas of the supreme good on the behaviour of babies, without sufficiently taking into account what it means to be an adult human being. ${ }^{42}$

Even though spiritual pleasure is more important than physical pleasure for Epicurus, the latter is still prominent in his writings about pleasure. ${ }^{43}$ It is undoubtedly because Seneca puts physical pleasure at the root of the problem, that he focuses on this kind of pleasure ${ }^{44}$ in his criticism of Epicurus. ${ }^{45}$ It is no coincidence that in vit. 5,4 the point of departure for his attack on Epicureanism is precisely physical pleasure. ${ }^{46}$ Also typical is the following turn of events in vit. 6,1 . When a fictitious opponent suggests that Epicureans recognize spiritual pleasures as well, Seneca zooms in on the arbitral role played by the animus regarding (physical) voluptates in the Epicurean interpretation, mocking the pleasure the Epicurean animus finds in

39 Cp. CiCERo, Tusc. V, 96: spiritual pleasure ranks higher than physical pleasure, because the latter is linked up with the present, while the former is found in past, present and future.

40 EPICURus, Men. 128; cp. CiCERO, fin. I, 38.

41 Cp. about Epicurus, KUEN (1994), p. 373-376, and also LS vol. 1, p. 112-125, and BRUNSCHWIG - SEDLEY (2003), p. 160-162.

42 The Stoics too depart from the analysis of a baby's behaviour for the development of their doctrine of oikeiosis. They are of the opinion that man's first impulse is self-preservation. However, for determining the supreme good, the Stoics also take into account what characterizes an adult human being.

43 LS vol. 1, p. 124. In this way, Epicurus taught, for instance, that spiritual pleasure has its roots in physical pleasure. See e.g. CiCERO, fin. I, 55 and II, 98 (Cicero says to the Epicurean: negas animi ullum esse gaudium, quod non referatur ad corpus); cp. e.g. also fin. II, 106 and 107, and III, 1.

44 Besides, Cicero too emphasizes the importance of physical pleasure in Epicureanism; see Tusc. III, 37 and 50. Cp. also CICERO, fin. III, 1: Etenim sit impudens (sc. voluptas), si virtuti diutius repugnet, aut si honestis iucunda anteponat aut pluris esse contendat dulcedinem corporis ex eave natam laetitiam quam gravitatem animi atque constantiam.

45 In his philosophical writings, Seneca repeatedly expressed his appreciation for Epicurus as a person, and for his teachings about paupertas. Although Epicurus regarded pleasure as the supreme good and therefore could be accused of mollitia, Seneca still considered him a brave man (fortis). In epist. 92, 26 the Epicureans are called degeneres et humillimae mentis. Cp. Cicero's attitude towards Epicurus in fin. II, 99.

46 See also KUEN (1994) ad loc. 
reliving and anticipating physical pleasures. The fact that Seneca is primarily talking about the soul's attention to physical pleasures is very clear from his turn of phrase, which includes luxuria; eis omnibus quae oblectare sensus solent; corpus, and sagina. This means that the reader can get the erroneous impression that Epicurus reduced pleasure to physical pleasure.

The kind of link between virtus and voluptas defended by Epicurus was totally unacceptable for Seneca. The former's view causes virtus to be lowered to the position of handmaiden of voluptas (virtus voluptatum ministra, ben. IV, 2, 1), which is put before everything else (epist. 90, 35; 92, 9 and ben. IV, 2, 1-4). Just how offensive Seneca would have found this opinion is clear from Cleanthes' visual representation of Epicurus' teachings, in which Voluptas sits on a throne surrounded by virtutes as her servants (see Cicero, fin. II, $69^{47}$ ). However, for the Stoa in general and Seneca in particular, it is beyond question that virtus should play the leading role.

Besides, voluptas cannot be the supreme good, since pleasure is a transient thing, which tunc cum maxime delectat extinguitur (vit. 7, 4). It is a pseudo-good, which exists in motion according to Seneca (cf. supra 2.2.), and is therefore per definition unstable (vit. 7, 4). Moreover, how could voluptas be the supreme good when Epicurus himself is forced to admit that voluptas needs to be controlled by ratio and virtus, while nothing can be greater than that which we accept to be the supreme good (vit. 11, 2 and 14, 1)?

In any case, virtus and voluptas differ fundamentally. In Seneca's view, they are inconvenientia - "irreconcilable things" (see vit. 12, 3) (cp. diversa and dissimilia in vit. 7, 1 and 3). Indeed, some things are pleasant, but not of high moral standing, while other things are of high moral standing, but not pleasant (vit. 7,1$).{ }^{48}$ Virtus is a thing of high moral standing; one finds it in temples, at the forum, in the senate and on the battlefield, while (physical or sensuous) pleasure is a base thing, voluptas being found in brothels and bars (vit. 7, 3). A telling passage is ben. IV, 2, 4: Non indignor, quod post voluptatem ponitur virtus, sed quod omnino cum voluptate! ${ }^{49}$ In epist. 92 , 9-10 Seneca compares the (Epicurean) combination of virtus and voluptas with the monster Scylla, as described by Virgil in Aen. III, 426-428, and in 92, 10 he calls it a discors... iunctura. Some lines later, in epist. 92, 24, we read that virtus does not even deign to look at pleasure! ${ }^{50}$

Many hedonists -for whom only physical pleasure is of importance ${ }^{51}$ according to Seneca in vit. c. 13- do not really know Epicurus' philosophy and only use it to cover up their own quest for pleasure (vit. 13; cp. epist. 21, 9 and const. $15,4)$. Turning Epicurus' interpretation of the link between voluptas and virtus upside down, the hedonist seems to think that a life full of pleasure will automatically be a morally excellent life; see vit. 12, 3: quia scit se cum voluptate vivere, credit et cum

47 Cp. also Augustin, civ. V, 20.

48 Cp. Chrysippus in Diogenes Laertius VII, 103 (RIST [1969)], p. 46 and GÖRLER

[1984], p. 399, n. 6): pleasure cannot be a good since some enjoyments are shameful.

49 Cp. CiCERo, fin. II, 37.

50 Cp. also CiCERO, fin. V, 22.

51 See KUEN (1994), p. 116 about the hedonists. 
virtute. ${ }^{52}$ The fact that the hedonists abuse the great importance a philosopher attached to pleasure, is an additional reason for Seneca to turn against Epicureanism in this respect. Indeed, in vit. 12, 5 we read: Hoc est cur ista voluptatis laudatio perniciosa sit.

2.4. From some passages in vit. 6-16, for instance, and from some extras to epist. 2-29, we can gather that Seneca, like Cicero for that matter, respected Epicurus as a person, and that, in a certain way, he also appreciated his choice for moderate pleasure. For example, Seneca talks very positively about Epicurus' moderate pleasure in epist. 18, 10. However, the importance attached to pleasure in Epicurus' teachings was unacceptable for Stoics, as it was for Cicero too. Evidently the polemical discussion between both Hellenistic schools led to black-and-white oppositions. A characteristic passage in this respect is ben. IV, 13, 1-2. The extract is quite appealing from a literary point of view and I wish to quote the part about the Epicureans $(\S 1)$ : Vobis voluptas est inertis otii facere corpusculum et securitatem sopitis simillimam adpetere et sub densa umbra latitare tenerrimisque cogitationibus, quas tranquillitatem vocatis, animi marcentis oblectare torporem et cibis potionibusque intra hortorum latebram corpora ignavia pallentia saginare. The Stoics, on the other hand, find pleasure in doing good deeds, including those that demand sacrifices and dangers, or cost money.

Both Cicero and Seneca stress that Epicurus advocated a rational, moderate pleasure, but on the other hand both acknowledge that Epicurus' theory could be interpreted to include pleasure that exceeds Epicurus' preferred moderation. With respect to Cicero, I only want to point out that he mentioned that Epicurus could not imagine good without the pleasures of food, sex and music. ${ }^{53}$ With respect to Seneca, I would like to argue the following:

(1) When it comes to Epicurus' teachings, Seneca (for instance in vit.) concentrates on voluptas as physical pleasure, and not on the fact that Epicurus placed spiritual pleasure above physical pleasure.

(2) Similarly, Seneca does not discuss pleasure as the absence of pain, but pleasure in the common sense of the word, without mentioning that Epicurus placed static pleasure above kinetic pleasure.

(3) Seneca judges the Epicureans' pleasure, in particular in the aforementioned ben. IV, 13, 1-2, to be a lazy pleasure.

(4) Finally, the Roman philosopher is convinced that it is safe to say that Epicurus' teachings open a door for pleasure that goes much further than what is "natural and necessary".

52 Cp. KUEN (1994), p. 173.

53 See Cicero, Tusc. III, 41-2 and 46 and fin. II, 30, and also AthenAEus of NAUCRATIS VII, $280^{\mathrm{ab}}$ and XII, 546 ${ }^{\mathrm{ef}}$ (= Usener 67). For Cicero, see STOKES (1995). 


\section{Gaudium s.s. ${ }^{54}$}

3.1. With virtus comes gaudium s.s. (Gr. chara). In epist. 59, 16 we read: gaudium hoc non nascitur nisi ex virtutum conscientia. Cp. epist. 27, 3: sola virtus praestat gaudium (perpetuum, securum). ${ }^{55}$

Only the wise man -the only one who is virtuous, the only one who performs katorthomata- knows this gaudium. In epist. 59, 2 we learn that gaudium nisi sapienti non contingere. In epist. 59, 14 Seneca states: sapiens ille plenus est gaudio.

In epist. 59, 2 Seneca defines this joy, as already mentioned, as animi elatio suis bonis verisque fidentis or as "an elation of the soul -a soul that trusts in the goodness and truth of its own possessions", which is Seneca's interpretation of the definition of chara as eulogos eparsis- "a rational elation (of the soul)" or "a rationally justifiable uplift (in the soul)". ${ }^{56}$ See also vit. 4, 4 suis gaudeat and ben. VII, 2, 4 suo contentus. Seneca stresses that there can only be gaudium if we focus on the true good that resides within us and do not lose ourselves in the pseudo-goods we cannot control. Chara or gaudium is one of the so-called (Stoic) good emotions, Gr. eupatheiai (Cic. constantiae). ${ }^{57}$

In certain contexts, Seneca may call this joy vera voluptas (vit. 4,2$)$. When debating with a fictitious representative of the Epicurean school, Seneca even unequivocally speaks of the voluptas that follows from virtus in vit. 9, 1-2, and we find the same in ben. VII, 2, 3-4. In epist. 59, 14 voluptas, gaudium and laetitia are used to denote the true joy.

3.2. In epist. 85, 18 we see that Seneca criticizes Epicurus for disconnecting virtus and voluptas, despite being convinced that with virtus always comes voluptas and conversely voluptas always requires virtus. The passage reads as follows: Epicurus (...) iudicat, cum virtutem habeat, beatum esse, sed ipsam virtutem non satis esse ad beatam vitam, quia beatum efficiat voluptas quae ex virtute est, non ipsa virtus. Inepta distinctio: idem enim negat umquam virtutem esse sine voluptate. Ita si ei iuncta semper est atque inseparabilis, et sola satis est; habet enim secum voluptatem, sine qua non est etiam cum sola est. ${ }^{58}$

However, Seneca too states that the gaudium that is inextricably bound up with virtus, is not part of the supreme good. In vit. 15, 2 we read: Ne gaudium quidem quod ex virtute oritur, quamvis bonum sit, absoluti tamen boni pars est, non magis quam laetitia et tranquillitas, quamvis ex pulcherrimis causis nascantur; sunt enim ista bona, sed consequentia summum bonum, non consummantia. Such gaudium is a by-

54 Laetitia is also used for this gaudium; see e.g. vit. 4, 4 (cp. 1.3. supra).

55 Cp. Diogenes LAertius VII, 94.

56 Cp. SVF index of Stoic terms, s.v. chara. "Eulogos eparsis" is found, for instance, in ANDronicus (I ${ }^{\text {st }}$ c. BC) (SVF 3, 432), and in Diogenes LAERTIUs VII, 116. In Tusc. IV, 12 Cicero opposes gaudium and voluptas in the following way: gaudium $=$ cum ratione animus movetur placide atque constanter; voluptas = sine ratione animi elatio.

57 See Diogenes LaerTiUs VII, 116. Cp. also BrenNAN (2003), p. 270.

58 About this passage, see INWOOD (2007), ad Sen. epist. 85, 18 (p. 229-230). 
product of virtus (vit. 9, 2 accessio $=$ Gr. epigennema; 8, 1 comes; 15, 2 bona ... consequentia summum bonum). ${ }^{59}$ An important difference with Epicureanism is obviously that the Stoic does not pursue virtus for pleasure, in casu spiritual joy. Virtus, the supreme good, is only pursued for itself $\left(v i t .9^{60}\right)$. While this specification of the precise position of the joy ensuing from the practice of virtue might seem somewhat superfluous at first sight, it is of great importance for the Stoa. It is meant to prevent virtus from being reduced to a means to achieve gaudium, a thing that would put the Stoa in the wake of Epicureanism. ${ }^{61}$

In this way, we not only gather from vit. 15, 2 that for Seneca gaudium is not part of the supreme good, but also that it is still a good. ${ }^{62}$ This characterization of gaudium or Gr. chara as a good is also found, for instance, in Stobaeus, ecl. II, p. 58, $5 \mathrm{~W}(S V F \quad 3,95)$ and II, p. $73,1 \mathrm{~W}(S V F) 3,111){ }^{63}$ Seneca's view (gaudium is a bonum) is easy to understand, since gaudium is so tightly bound up with virtus.

3.3. Seneca also mentions the fact that the wise man's gaudium is an incessant joy. Obviously, this stability has to do with the stable attitude (Gr. diathesis) that characterizes the wise man specifically (Gr. bebaiotês). See e.g. Seneca, epist. 95, 57 and $120,10 .{ }^{64}$ Seneca speaks of "a joy that is unbroken and continuous" (epist. 59, 16 : gaudii aequalitas) and an unending joy: gaudio autem iunctum est non desinere nec in contrarium verti (epist. 59, 2; cp. 59, 14 and 18, and 81, 24). In epist. 27, 3 we read: Sola virtus praestat gaudium perpetuum. Cp. also vit. 3, 4 ingens gaudium subit inconcussum et aequale and vit. 4, 4 hilaritas continua et laetitia alta. This joy is also called laetitia... maxima, continua (epist. 73, 8). Elsewhere, in ben. VII, 2, 4, Seneca calls this "pleasure" voluptatem aequalem, intrepidam, numquam sensuram sui taedium (the latter in contrast with the case of passionate pleasure!). ${ }^{65}$

59 Cp. Diogenes LAERTIUS VII, 94, in this context correctly adduced by ForsCHNER (1981), p. 140 and GöRLER (1984), p. 407. DiOgENES LAERTIUS VII, 94 deals with arete and its parts; according to Diogenes Laertius chara is not a part of arete, but an epigennema of it. This matches Seneca's teachings about gaudium as accessio! See SENECA, epist. 66, 25: omnia enim alia non partes sed accessiones sunt. KUEN (1994), p. 369 refers to DIOGENES LAERTIUS VII, 85-86 with respect to a "vernünftige(r) Lustzustand". She presumes that when DiogenES LAERTIUS VII, 85-6 advances that hêdonê is linked as an epigennema to an action necessary for self-preservation, he actually means chara. RIST (1969), p. 49 (cp. p. 45-46) for that matter comments on Diogenes LAERTIUS VII, 102 (where hêdonê is classified among things preferred): "Hêdonê is being used in a general sense; and doubtless chara is to be understood in this context as one of its species." In my opinion, when it comes to gaudium, it is better to refer to Diogenes Laertius VII, 94, where he talks about chara as one of the epigennemata connected to virtus. Besides, epigennema has no separate lemma in the index of technical terms in part 4 of $S V F$, and accessio is found in Seneca in various contexts.

60 Cp. e.g. CICERO, fin. I, 61.

${ }^{61}$ So KuEn (1994), p. 367 correctly. Cp. ForsCHNER (1981), p. 213-214.

62 Cp. also epist. 66, 5 and see InWOOD (2007), ad Sen. epist. 66, 5-6, p. 158-160.

63 Cp. FORSCHNER (1981), p. 213.

64 See e.g. DONINI (1999), p. 715-716.

65 Cp. GÖRLER (1984), p. 411-412. 
Referring to Stobaeus, who in ecl. II, p. 68, 24-p. 69, 4W and II, p. 77, 6-10W (SVF 3, 103 and 3,113) judges that chara is not a necessary component of eudaimonia, ${ }^{66} \mathrm{~W}$. Görler ${ }^{67}$ argues in epist. 59, 16 (sapiens... numquam sine gaudio est) Seneca erroneously states that the wise man is always joyful. ${ }^{68}$ Whether the wise man actually knows joy, which is different from virtus and eudaimonia, depends, according to W. Görler, on whether or not his virtuous conduct "achieves results", which is what Cicero calls consequentia (text in n. 69). In my opinion, W. Görler's reasoning is incorrect. Joy is an accessio of virtus. The wise man practices virtus perfectly even under the most ungrateful conditions. In doing so, not the consequentia of his actions are important, but his attitude and intentions. In this respect, we should heed, for instance, ben. II, 31, 1 et cum pietas, fides, iustitia, omnis denique virtus intra se perfecta sit, etiam si illi manum exserere non licuit, gratus quoque homo esse potest voluntate. ${ }^{69}$ Accordingly, in my opinion, Seneca correctly contends that the wise man always knows joy. A good illustration is, for instance, ira II, 6, 2: Gaudere laetarique proprium et naturale virtutis est. $\mathrm{Cp}$. also vit. 4, 2: the wise man is virtute laetus.

However, the argument Seneca himself advances for his thesis that the wise man's joy is an incessant joy, is not the one I have just advanced in reply to W. Görler. Seneca discusses this point in epist. 59, 18: illud gaudium quod deos deorumque aemulos sequitur non interrumpitur, non desinit; desineret, si sumptum esset aliunde. Quia non est alieni muneris, ne arbitrii quidem alieni est: quod non dedit fortuna non eripit. In other words, gaudium s.s. comes from the wise man himself; it is not a gift of Fortuna, who accordingly cannot take this gaudium away... Cp. also epist. 72,4 .

3.4. As already mentioned, according to Seneca, the joy (gaudium s.s., Gr. chara) we are discussing here, is only known to the wise man. Only he possesses the virtus to which this gaudium belongs, only he possesses the stability that leads to this stable gaudium.

66 Cp. also Diogenes LaerTius VII, 98.

67 (1984), p. 411-412.

68 GÖRLER (1984), p. 412 is of the opinion that Seneca confuses happiness with joy (compare the way Motto refers to "happiness"" s.v. "joy" and vice versa!). I do not think it is fair to claim this. However, it is true that Seneca sometimes presents happiness and joy in a way that may come across as strange to the theorist, who expects matters distinguished theoretically by Seneca to be presented separately in his discourse.

69 Cp. CicERo, fin. III, 32: Quicquid enim a sapiente proficiscitur, id continuo debet expletum esse omnibus suis partibus; in eo enim positum est id quod dicimus esse expetendum. Nam ut peccatum est patriam prodere, parentes violare, fana depeculari, quae sunt in effectu, sic timere, sic maerere, sic in libidine esse peccatum est etiam sine effectu. Verum ut haec non in posteris et in consequentibus, sed in primis continuo peccata sunt, sic ea quae proficiscuntur a virtute susceptione prima, non perfectione recta sunt iudicanda. See DonINI (1999), p. 717. Cp. also FORSCHNER (1981), p. 177-178. 
According to W. Görler's study on the Old Stoa, proficientes performing kathekonta, actions according to nature, should also experience moments of chara / gaudium, a kind of eulogos eparsis, a rationally-founded pleasure.

One of W. Görler's arguments is that the term eulogos, which is present in the definition of chara as eulogos eparsis, is also present in the definition of kathekonta (Diogenes Laertius VII, 107). However, as for this argument, we need to remark that, as M. Forschner ${ }^{70}$ explains, logos is not always to be equated with the orthos logos, which performs virtuous actions, so that eulogos does not always mean exactly the same thing either. In performing kathekonta, the proficiens is indeed guided by reason, but specifically by the choosing logos (Diogenes Laertius VII, $108^{71}$ ). He does not have the capacity for virtuous conduct, for katorthomata, where the orthos logos is at work (see Stobaeus, ecl. II, p. 96, 18W; SVF 3, 50172).

Of course, the so-called chara / gaudium of the proficientes does not have, as W. Görler is well aware of, the stability of the wise man's gaudium, as the proficientes do not know the wise man's stable virtuous dispositio. W. Görler ${ }^{73}$ also concedes that we do not know which term the Stoa would have used for the rationally-founded pleasure of the non-wise.

Still, W. Görler contends ${ }^{74}$ that Seneca represents a hard line when he reserves gaudium for the wise man in epist. 59, 2. Moreover W. Görler argues ${ }^{75}$ that Seneca is mistaken in 59, 16, where he defines gaudium as joy that comes from the awareness of practicing virtus.

For Seneca there is indeed a radical difference between the sapiens and the proficientes. However, this was also the case in the Old Stoa! To some degree, W. Görler obscures the radical difference between sapiens and proficientes. $^{76}$ Seneca's opinion that chara is reserved for the wise man is also found in Philo Judaeus, Legum allegoria 3, 247 (SVF 3, 671: Gr. ho faulos... mêden echôn charas aition), and in Diogenes Laertius VII, $94 .^{77}$

I concede that the kathekonta of the proficientes and the wise man's katorthomata are rationally-founded actions, actions according to nature, ${ }^{78}$ yet only the actions performed by the wise man are virtuous actions, performed from a specific and stable virtuous dispositio. Indeed, the proficientes too can perform rationally-founded actions accompanied by an honorable pleasure that can be appreciated in a positive

70 (1981), p. 183-211.

71 FORSCHNER (1981), p. 185. Cp. also p. 115 referring to PlUTARCH, vir. mor, 3, 441c (SVF 3, 459): Gr. ton hairounta logon.

72 And FORSCHNER (1981), p. 189.

73 (1984), p. 410.

74 (1984), p. 407.

75 (1984), p. 410, n. 28.

76 He does so, for instance, on p. 406 sq., and in a striking way in Figur 4, p. 410. Compare how BorGo (1998) insufficiently relates gaudium s.s. to the wise man, and insufficiently clearly and systematically distinguishes it from voluptas.

77 Cp. also CiCEro, Tusc. IV, 12 (SVF 3, 438); see GÖrLER (1981), p. 407.

78 See e.g. DONINI (1999), p. 729, and formerly FORSCHNER (1981), p. 196 sq. 
way. We will return to the spiritual pleasure that comes with the kathekonta of the proficientes under 4.6.2 infra. ${ }^{79}$

In Seneca gaudium s.s. is regularly mentioned as a future perspective for the proficiens, not as something the proficiens possesses. A characteristic instance of this is letter 23 or also epist. 59, 14-18. See, for instance, epist. 23, 4: in huius gaudii possessione esse te volo.

Moreover, Seneca regularly underscores the fact that people often look for true joy, gaudium, in the wrong things. In epist. 59, 14-15 we read that people mistakenly look for gaudium in (for instance) riches, honorary positions, the people's affection, a girlfriend, knowledge to show off - all things that do not create gaudium, but worries. In 59, 17-18 falsa gaudia are mentioned twice, and in 59, 15 we read about oblectamenta fallacia.

3.5. Despite arguing that gaudium s.s. is not part of the supreme good, but an accessio of it, and that one strives for virtus because of virtus itself, Seneca has praised the "true joy", which one experiences when acting in perfect accordance with morality, on several occasions in his philosophical works. For instance, in letter 23 and letter 59, 14-18.

\section{Voluptates naturales / honestae / permissae and voluptates inprobae / inlicitae ${ }^{80}$}

4.1. So is there, in the eyes of the Stoic Seneca, no other acceptable pleasure besides the wise man's gaudium s.s. (Gr. chara) or vera voluptas, the spiritual voluptas that is an accessory of virtus? Contrary to what many think, the answer is "yes", even if I immediately have to concede that it is clearly a case of "yes but...".

A big but indeed. Voluptas - the antithesis of virtus in the debate about the supreme good - very often has a negative connotation in Seneca's philosophical works, even if the term does not specifically refer to erroneous pleasure or pathos. This is the case, for instance, in De vita beata. Like Plato, who called pleasure

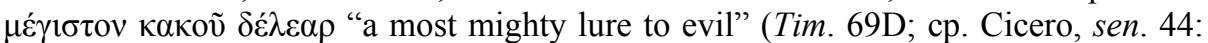
escam malorum, Seneca too views pleasure as the enticing bait of many vices, as we read in brev. 10, 3: vitia... quae aliquo praesentis voluptatis lenocinio subrepebant. As we will see, a Stoic must not do anything voluptatis causa. Especially striving for physical enjoyments is forbidden. In epist. 110, 10 we even hear: Addiximus animum voluptati, cui indulgere initium omnium malorum est! Not only the future enjoyments, but also those from the past do damage to us (epist. 27, 2).

Sub 2 (Seneca on Epicurus) we have not only seen that voluptas (pleasure, and chiefly physical pleasure) cannot be the supreme good for Seneca (in his view, virtus is the supreme good), but also that it is unacceptable to use virtus for the purpose of

79 GÖRLER (1984), p. 411 points out that the wise man knows only chara anymore and never relapses into erroneous hêdonê. That the wise man never relapses into erroneous hêdonê, is true, yet we will see further on that when it comes to the wise man, Seneca also takes into account acceptable, light voluptates.

80 For these terms, see e.g. Marc. 3, 3; ira III, 42, 2, and epist. 27, 2. 
voluptas. Seneca even takes matters a step further: in the context of his polemical discussion with Epicureanism (vit. 6-16) he does not hesitate to dub the association of virtus with voluptas an association of inconvenientia (vit. 12, 3)! Cp. also ben. IV, 2 conclusion!

Only when virtus is in charge, as we read further on in the text, can there be some limited room for voluptates outside of gaudium s.s. In vit. 13, 5 we read Agedum, virtus antecedat, tutum erit omne vestigium... Only under the safe guidance of virtus, voluptas can be tolerated, if you really deem some kind of link between virtus and voluptas desirable. Si hoc placet ad beatam vitam ire comitatu, virtus antecedat, comitetur voluptas et circa corpus ut umbra versetur... The expression in the final part shows that Seneca is thinking of voluptas as physical enjoyments here (as indeed often). Moreover, what he says amounts to tolerating innocent (physical) pleasure, not nourishing it! Physical pleasure is only acceptable as long as it serves proper the functioning of the body. We will see what this means exactly sub 4.7.1 infra.

4.2.1. In vit. 22, 3-4 we find a fundamental statement from Seneca regarding the fact that there are other things outside of virtus that hold some worth and can be of some meaning for man, albeit more for the proficiens than for the sapiens (cp. vit. 16, $3 !^{81}$ ) and in comparison very little (cp. infra): Quaedam enim, etiam si in summam rei parva sunt et subduci sine ruina principalis boni possunt, adiciunt tamen aliquid ad perpetuam laetitiam et ex virtute nascentem (\$3). ${ }^{82}$ Quis porro sapientium nostrorum dico quibus unum est bonum virtus - negat etiam haec quae indifferentia vocamus habere aliquid in se pretii et alia aliis esse potiora? (§4). ${ }^{83}$ Against this backdrop, Seneca argues that he prefers a peaceful, pleasant life to a tough and painful life. See vit. 25, 5 Totum fortunae regnum despiciam, sed ex illo, si dabitur electio, meliora sumam. Quidquid ad me venerit bonum fiet, sed malo faciliora ac iucundiora veniant et minus vexatura tractantem. See also epist. 92, 11-13 and 17. In epist. 92, 11 Seneca says without hesitation that, given the choice, he would prefer good health and the absence of pain to illness and pain. But why does the Stoic prefer these commoda? Non quia bona sunt, sed quia secundum naturam sunt, et quia bono a me iudicio sumentur (cp. epist. 92, final part 13). ${ }^{84}$ See also infra on this correct attitude!

81 Quid ergo ? Virtus ad beate vivendum sufficit? - Perfecta illa et divina quidni sufficiat, immo superfluat?... Quid extrinsecus opus est ei qui omnia sua in se collegit? Sed ei qui ad virtutem tendit, etiam si multum processit, opus est aliqua fortunae indulgentia adhuc inter humana luctanti etc.

82 Without further comment, KUEN (1994), p. 259, n. 29 points out that Seneca says something else in vit. 4, 3: cetera vilis turba rerum nec detrahens quicquam beatae vitae nec adiciens. It is not unusual for Seneca to say about something that counts very little, that it does not count at all.

83 Both $\S 3$ and $\S 4$ deal with indifferentia. Based on the expression, one could hesitate in the case of $\S 3$, yet the sentence that follows the part of $\S 3$ we cited, makes it absolutely clear that $\S 3$ deals with indifferentia, just like $\S 4$.

84 See also vit. 25, 5 and KUEN (1994) ad loc. Cp. also epist. 66, 19. However, elsewhere Seneca is also found to say that he sees the advantages of dire circumstances of life, and that 
Now besides riches, good health, and so forth, Seneca also considers the voluptates outside of gaudium as preferable indifferentia (commoda; for this term see e.g. vit. 24, 5). In epist. 76, 18 voluptas is named together with pecunia and potentia, in epist. 87, 29-35 together with divitiae and bona valetudo, and in epist. 123, 13 together with divitiae, forma and ambitio. ${ }^{85}$

In his self-defence (part II of vit.) Seneca explicitly argues that, given the choice, he would prefer riches to poverty. Still, he will not get attached to these riches and use his possessions for positive actions (e.g. beneficia). When it comes to acceptable voluptates Seneca cannot bring himself to a more or less similar statement. He is the spokesman of virtus; in no way does he wish to advertise voluptates, especially physical voluptates.

In this way, voluptas is one of the preferable indifferentia for Seneca. Such a voluptas is, unlike gaudium, not a bonum (see e.g. vit. 10,3). However, one can still deal with it either in a good way (see epist. 92, 13 bono... iudicio, cited in the above) or in a bad way. In the latter case, this amounts to pathos (cf. infra!).

The different Stoics defined hêdonê or voluptas in various ways. Seneca's point of view adheres to that of Chrysippus. Ranking good, bad and indifferent things, Diogenes Laertius writes in VII, 102-103 (SVF 3. 117 and 156; LS vol. 1, 58A) that the Stoa (Chrysippus is named explicitly) saw hêdonê as something indifferent yet preferable. In a short overview of the opinions on pleasure, Aulus Gellius IX, 5, 5 notes that Zeno classified pleasure as something indifferent. Stobaeus, ecl. II, p. 57, 18-19W (SVF 1. 190 and 3. 70) also ranked hêdonê as something indifferent. In Sextus Empiricus, adv. math. XI, 73 (SVF 3.155) we read that hêdonê is a good thing for Epicurus, but for the Stoa an indifferent thing that is not preferable. Cleanthes is said to have found hêdonê neither natural nor valuable, and Archedemus apparently viewed hêdonê as a natural, yet worthless thing. ${ }^{86}$

4.2.2. In this way, Seneca follows Chrysippus and ranks pleasure among the preferable indifferentia. In epist. 116, 3 we also read: Voluptatem natura necessariis rebus admiscuit, non ut illam peteremus, sed ut ea sine quibus non possumus vivere gratiora nobis illius faceret accessio.

In the eyes of the Epicureans, pleasure is man's primary impulse and his highest purpose. In Diogenes Laertius VII, 85-86 we read that for the Stoa not pleasure, but self-preservation is man's first impulse; hêdonê is merely an epigennema that comes with the efforts man makes to realise self-preservation and self-

virtus exercised in difficult circumstances rouses more admiration, even if all bona actually weigh the same. See prov. 4, 4; epist. 66, 49 sq. and 82, 1-2, and Inwood (2007), ad Sen. epist. $66,47 \mathrm{sq}$.

85 Cp. also epist. 84, 11 (divitiae, corporis atque animi voluptates, ambitus) and 109, 18 (voluptas mentioned together with gloria). In Tusc. IV, 66 Cicero mentions voluptates among the bona divitiae and honores (bona is used here in its common meaning!). Cp. also DiOGENES LAERTIUS VII, 102. See also BRENNAN (2003), p. 269-270.

86 See LS vol. 1 (ad 65), p. 421 and vol. 2 (ad 57A9 epigennema), p. 343; (ad 58A), p. 349-350; (ad 65A8-9 hêdonê), p. 405. See also RIST (1969) and GöRLER (1984). 
development. In Seneca, epist. 116, 3 we learn the function of this epigennema hêdonê or voluptas.

4.2.3. In the same vein, Seneca stresses several times - perhaps not so much as a Stoic, but as somebody who has common sense- that for the wise man and for any human being some degree of variation between heavy duties and light relaxation is necessary. He does so, for instance, in vit. 12, 2, where we read about the wise that miscent enim illas (sc. voluptates) et interponunt vitae ut ludum iocumque inter seria. Cp. especially the final part of tranq., namely 17, 4-11. In 17, 4 we read: Nec in eadem intentione aequaliter retinenda mens est, sed ad iocos devocanda and in 17, 5: danda est animis remissio. Similarly, we find the following regarding the education of children in ira II, 20, 3: Lusus quoque proderunt; modica enim voluptas laxat animos et temperat. Perhaps such statements amount to more than a policy of tolerance after all...

I add some additional details about tranq. 17, 4-11. Seneca mentions several forms of naturalis ... voluptas $(17,6)$ : iocus - "amusement" ( $\$ 4$ and 6), lusus "sports" ( $\$ 4$ and 6), vinum ( $\$ 4$ and 8-9), dance ( $\$ 4)$, walking $(\S 8)$, travelling $(\S 8)$, attending public festivities $(\$ 7)$. When Seneca judges relaxation necessary for body and soul, he is actually paying attention to the psychosomatic. All things considered, he is quite lenient here and for a moment even accepts some degree of ebrietas (§9) (a small mistake?)! ${ }^{87}$ However, there is also some hesitation: he speaks of naturalis quaedam voluptas ( $(6)$, "a sort of pleasure that (is) natural", and on more than one occasion underscores the importance of moderation ( $\$ 9$ moderatio).

4.3. In this section, we will deal with the different kinds of voluptates that fall outside of the aforementioned gaudium or vera voluptas.

4.3.1. First of all Seneca distinguishes between spiritual and physical pleasures. ${ }^{88}$ Epist. 78, 22 is very clear in this respect: Praeterea duo genera sunt voluptatum. Corporales ... bibere ... cibus ... Illas vero animi voluptates, quae maiores certioresque sunt. ${ }^{89}$ Following the tradition, Seneca places the spiritual pleasures above the physical. ${ }^{90}$

J.M. Rist (1969) ${ }^{91}$ expresses doubts concerning a terminology that could in some way imply that the Old Stoa distinguished purely "physical" pleasures from pleasures in which the mind is involved. In his view, such an interpretation does not fit with the concept of man the Old Stoa had, but rather wtih the more dualistic

87 Elsewhere Seneca turns against drunkenness; see MOTTO (1970), p. 69-70, s.v. drunkenness. In Diogenes LAERTIUS VII, 118 we read that the wise man is allowed to drink wine, but must not be drunk.

88 Cp. FORSCHNER (1981), p. 117 on the division of preferable adiaphora into spiritual, physical and external matters.

89 Cp. also epist. 84, 11 corporis atque animi voluptates.

90 See INWOOD (1999), p. 695 and n. 58.

91 P. 38 sq. 
perspective of, for instance, Posidonius and Epictetus. He suggests ${ }^{92}$ to speak of "first-order pleasures" with regards to so-called physical pleasures, "the simple feeling of "physical' satisfaction" and of "second-order pleasures" with regards to "the more psychologically complex pleasure." He concludes: ${ }^{93}$ "that every act of every human being, young or old, mature or immature, is both a rational and a physical act. Hence there can be no such thing as a purely 'bodily' or 'physical' pleasure". 94

4.3.2. Apart from the distinction between spiritual and physical enjoyments, Seneca also makes a distinction between acceptable, natural, moderate enjoyments and non-acceptable, unnatural, immoderate ones. In my view, we can state that when it comes to the immoderate kind, Seneca first and foremost thought of physical enjoyments.

Someone who allows pleasure, for Seneca in itself a preferable indifferent thing, would come to disgraceful conduct, nisi aliquis distinxerit illi voluptates, ut sciat quae ex eis intra naturale desiderium ${ }^{95}$ resistant, quae praeceps ferantur infinitaeque sint et quo magis implentur eo magis inexplebiles (vit. 13, 4).

(1) The essential characteristic of acceptable, natural pleasures (see naturalem... voluptatem, tranq. 17,6 ) is, in Seneca's view, that they are moderate. In some cases of (spiritual) pleasure he speaks of "honourable" pleasure (Marc. 3, 3 and ira III, 42, 2 voluptatem honestam).

These pleasures are tied up with the satisfaction of natural needs. Man has no other choice but to fulfil such natural needs. Besides, their satisfaction is not that difficult (epist. 119, 12 and 15), yet moderation is $(119,10)$. Very instructive in this respect is epist. 119, 2: Nec illud praecipio, ut aliquid naturae neges - contumax est, non potest vinci, suum poscit - sed ut quidquid naturam excedit scias precarium esse, non necessarium. Elsewhere (viz. in 119, 4; 10 and 15) non necessarium is called supervacuum. What we read in epist. 119 corresponds to what Seneca wrote in epist. $21,9 b-11$, when commenting a quote from Epicurus (discussed in the above sub 2.2). ${ }^{96}$

In this way, the pleasures that Seneca judges acceptable are those that meet natural needs and are characterized by moderation.

(2) Non-acceptable, erroneous pleasures (epist. 27, 2 inprobarum voluptatum; cp. Marc. 1, 7 prava voluptas) are called inlicitis voluptatibus in epist. 108, 14. Obviously, the pathos pleasure is meant here (adfectus: epist. 51, 8; 59, 4 and 116, 3).

92 P. 38.

93 P. 41.

94 Cp. also FORSCHNER (1981), p. 135: "Nun ist Rist sicherlich darin rechtzugeben, dass für die Stoa jeder Zustand und jede Bewegung des Menschen zugleich eine rationale und physische Seite hat."

95 Cp. epist. 119, 12: naturalibus desideriis and tranq. 9, 2: desideriis naturalibus.

96 InWOOD (1999), p. 695-697 discusses the fact that some Stoics contested the link between "natural and necessary". 
In such cases, we are dealing with something bad, a malum (epist. 59, 3), a vice (vitium, epist. 59, 1 and 95, 33, and ben. IV, 11, 5).

In epist. 59, 4 Seneca characterizes the pathos pleasure as something opinione falsi boni motam, inmoderatam et inmodicam - "it is inspired by an erroneous opinion concerning a false good; it exceeds control and is unrestrained". As already mentioned, this corresponds to what the Old Stoa called an alogos eparsis, "an elation of the soul disobedient to reason". ${ }^{97}$

When it comes to the pathos pleasure, we are first of all dealing with an erroneous judgment. In this case, alogos does not mean that the logos plays no part, but that the logos has made an erroneous movement, in other words a mistake. ${ }^{98}$ In many cases, this is because people mistakenly judge something that exceeds the natural boundaries to be a valuable or good thing, while in reality it is morally wrong and reprehensible.

However, there is also excessive excitement at work here. ${ }^{99}$ It is a case of not being able to keep pleasures in check (epist. 78, 27 voluptatibus vanis et ideo infinitis). Besides, we read nullum intra se manet vitium in epist. 95, 33. In such cases, man looses control over the situation. ${ }^{100}$

In epist. 116, 3, for instance, Seneca stresses that it is easier not to admit passion than to shut it out after having allowed it: excluditur facilius quam expellitur. This is a consequence of the fact that a passion is initially weak but gains in power afterwards. In the same paragraph Seneca even says: Quis negat omnis adfectus a quodam quasi naturali fluere principio? Curam nobis nostri natura mandavit, sed huic ubi nimium indulseris, vitium est.

(Immoderate) pleasure is one of the four primary passions that the Stoics distinguish (fear, desire, pain, pleasure or hêdonê). ${ }^{101}$ Eliminating the passions, freeing oneself from passion, is one of man's most important duties for the Stoa. ${ }^{102}$

97 "Alogos eparsis" is found, for instance, in ANDRONICUS ( ${ }^{\text {st }}$ c. BC), SVF 3, 391, and in Diogenes LAerTiUS VII, 114. Andronicus' definition of hêdonê is: "Hêdonê is a nonrationally-founded elation; it is the conviction that something good is present, by which one needs to be elated." Cicero's definition of voluptas in Tusc. III, 24 comes close to this, closer than Seneca's. Cp. also fin. II, 13.

98 See FORSCHNER (1981), p. 121-122.

99 See LS vol. 1, p. 421; cp. BRENNAN (2003), p. 269-270. With regards to pathos in the Old Stoa, GöRLER (1984), p. 402 sq. speaks of either an erroneous goal or a correct goal coupled with excessive excitement (take particular note of footnote 17 p. 402). Compare, for the immoderate aspect of passion, its description as Gr. hormê pleonazousa, GöRLER (1984), p. 402. Cp. also a number of expressions in Cicero, e.g. Tusc. III, 23: inmoderata laetitia, quae est voluptas animi elata et gestiens, and III, 24: (a passion is) animi motus vel rationis expers vel rationem aspernans vel rationi non oboediens, and ibid. also: voluptas gestiens, id est praeter modum elata laetitia, opinione praesentis magni alicuius boni. Cf. STOBAEUS, ecl. II, p. 90, 7 - 18W (SVF 3, 394) and INWOOD (1999), p. 701.

100 INWOOD (1999), p. 702.

101 See e.g. Diogenes Laertius VII, 110; Stobaeus, ecl. II, p. 88, 8 - p. 90, 18W (SVF 3, 378 etc. and LS vol. 1, p. 412), and INWOOD (1999), p. 701.

102 See e.g. Donini (1999), p. 711 sq. Seneca talks in detail about passions in De ira. 
4.4. What is the proper attitude with respect to voluptas / pleasure ? We are dealing with acceptable pleasure if we give pleasure its proper place and handle it in a proper manner.

(1) In this way, one needs first of all to distinguish between acceptable and unacceptable voluptates correctly. Grosso modo this amounts to the distinction between natural enjoyments and enjoyments that do not respect the boundaries fixed by nature. See vit. 13, 4 (cited above). ${ }^{103}$

(2)-(7) In vit. 10, 3 we read several instructions concerning the attitude we need to adopt with regards to voluptates. I quote the passage in full: ... virtus... voluptates aestimat antequam admittat nec quas probavit magni pendit: <caute> utique enim admittit nec usu earum sed temperantia laeta est. ... Tu voluptatem complecteris, ego compesco; tu voluptate frueris, ego utor; tu illam summum bonum putas, ego nec bonum; tu omnia voluptatis causa facis, ego nihil (caute is a coniectura; $t u=$ you, viz. an Epicurean; ego = I, viz. a Stoic).

(2) In vit. 10, 3 we read that virtus assesses the pleasures before admitting them. We should notice that Seneca apparently finds it acceptable to admit certain pleasures (admittere), yet not to pursue them (cf. infra).

(3) Seneca keeps repeating that the importance of preferable indifferent matters, because that is what we are dealing with, is minimal for human happiness or human beings in general. See e.g. epist. 66, 35: Ratio ergo arbitra est bonorum ac malorum; aliena et externa pro vilibus habet, et ea quae neque bona sunt neque mala accessiones minimas ac levissimas iudicat; omne enim illi bonum in animo est (and also 66, 46). ${ }^{104}$ For the Stoics in general and for Seneca in particular, the acceptable pleasures that fall outside of gaudium are minor affairs and of very little worth. Seneca says as much, for instance, with the hyperbole Voluptas humilis res et pusilla est et in nullo habenda pretio (epist. 123, 16) (cp. B. Inwood (2007) ad loc.). ${ }^{105}$

(4) We need to use our heads in dealing with pleasures, that is the advice of vit. 10, 3. After having stressed in epist. 72,7 that a human being needs to look for the more stable happiness in itself, cuius perpetua futura laetitia est, is suo gaudeat, Seneca adds the following concerning external matters: Sed haec quoque fortuita tunc delectant cum illa ratio temperavit ac miscuit.

${ }^{103} \mathrm{Cp}$. the expression of const. 12, 1: voluptatium sine dilectu adpetentes.

104 Compare, for instance, also epist. 92, 24: Virtus enim tantum bonum est ut istas accessiones minutas non sentiat. In this way, Seneca not only uses the term accessio for the gaudium that comes with virtus, but also for the other, smaller enjoyments that naturally come with necessary actions and a natural state. For this usage of accessio, we can refer to DIOGENES LAERTIUS VII, 85-86, where hêdonê is discussed as epigennema of doing what is necessary for self-preservation, and is accordingly used in a neutral or a positive sense. Compare Seneca's expression with CICERO, fin. V, 71: Ita enim parvae et exiguae sunt istae accessiones bonorum, ut, quem ad modum stellae in radiis solis, sic istae in virtutum splendore ne cernantur quidem; cp. also fin. V, 45 regarding voluptas.

105 Cp. also GöRLer (1984), p. 398 about the Old Stoa. 
(5) We do indeed need temperantia or "moderation". This thought is expressed repeatedly. Seneca regularly talks about confining enjoyments and the difficulty of doing so. In this respect, he frequently uses the words temperate, temperantia and temperator (vit. 10, 3; 14, 2; epist. 23, 6; 88, 29; 104, 13); also moderatio (epist. 23, 6) and modus (epist. 23, 6 and 95, 23); compescere (vit. 10, 3 and epist. 121, 4), coercere (epist. 58, 29) and frenum (epist. 23, 4). Being moderate when it comes to pleasures is a difficult matter, see e.g. epist. 23,$6 ; 39,5$ and $119,10 .^{106}$

(6) Ibid., so still in vit. 10,3, we hear that uti is the word indicating the correct attitude in handling voluptates, not frui. In case of uti, pleasure is not a goal in itself, unlike the situation in case of frui. We can make good use of voluptates, we need to deal with them properly, but we cannot focus on pleasure for the sake of pleasure. See also concerning frui: ira III, 5, 5 luxuria ... sua voluptate fruitur. ${ }^{107}$

(7) Indeed, the Stoic, both the wise and the proficiens, does nothing voluptatis causa (vit. 11, 1; see already c. 9; cp. the expression in De otio 6, 1, and also sectari voluptatem, in vit. 14, 3) ${ }^{108}$ For Seneca it is of crucial importance that one does not pursue pleasure (this even goes for gaudium, cf. supra). Pursuing all kinds of pleasure all the time (appetere) does not produce happiness (epist. 59, 14). Pleasure as such is a fortiori not the main goal of the Stoic's life.

4.5. What are the negative consequences of the pathos pleasure, i.e. of an improper attitude with respect to voluptas?

(1) Such enjoyments become sorrow and torture (epist. 23, 6; 24, 16 voluptates in tormenta vertuntur). They are a source of suffering (epist. 51, 8; 59, 14; 91, 5 and 121, 4) and restlessness (epist. 59, 14-5; brev. 17, 1). Physical enjoyments end in physical torture, libido for example in pedum, manuum, articulorum omnium depravationes (epist. 24, 16).

(2) The supreme good never leads to loathing, but pursuing (physical) pleasure ends in "disgust" (taedium, vit. 7, 4 and epist. 59, 15; fastidium, ben. VII, 2, 2; cp. ben. VII, 2, 4; cp. also epist. 119, 15-16).

(3) One often regrets the pathos pleasure afterwards (vit. 7, 4; vit. 12, 1; epist. 23, 6: vanas... voluptates, breves, paenitendas ac... in contrarium abituras; epist. 83, 27 and ben. VII, 2, 2; cp. paenitentia in epist. 27, 2; 74, 15; and in De otio 7, 3).

(4) Such pleasure weakens man (vit. 11, 1). Swayed by pleasure's power, we lose our resistance against ordeals, see vit. 13, 4: qui voluptatem sequitur videtur enervis, fractus... and epist. 92, 10: voluptas... dissolvit et omne robur emollit. Pleasure corrupts body and soul (e.g. ira II, 25, 3). Cp. also epist. 84, 11.

106 A telling example is that CICERO, fin. V, 67 defines the cardinal virtue temperantia as the correct way to deal with pleasure!

${ }^{107}$ To illustrate the difference between frui and uti KUEN ad loc. refers to AUGUSTIN, civ. $\mathrm{XI}, 25$; see in this respect especially Augustin's work De doctrina christiana. Voluptate frui is wrong, virtute frui is recommandable (CICERO, fin. I, 40 and IV, 15 respectively) (see also KUEN ad loc.).

108 Cp. Chrysippus (Rist [1969], p. 47). 
(5) Above all, Seneca fears that pleasure will weaken man's commitment. Someone who puts pleasure first is not a reliable defender of his country or his friends (vit. 15, 4; cp. 11, 1).

(6) Seneca fears that pleasure will control the one who chases it: non ipsi voluptatem, sed ipsos voluptas habet (vit. 14, 1; cp. 8, 2). In epist. 39, 5-6 we read that there is a risk that superfluous matters (supervacua) become indispensable (necessaria) and that one is enslaved by the voluptates. By chasing enjoyments we more and more depend on fortuna for our happiness, in other words on something that resides outside of our own person (vita 15, 3-4; cp. epist. 98, 1). In this way, we lose our freedom (see vit. 15, 3).

4.6.1. Many spiritual pleasures that fall outside of gaudium s.s. or the wise man's stable spiritual joy, are not a problem at all. On the contrary, many spiritual enjoyments of the non-wise, namely the proficientes, have an honourable ground as well (cp. the expression epist. 59, 4: quamvis enim ex honesta causa inperitus homo gaudeat $\left.^{109}\right)$. Regarding the spiritual enjoyments in question, Seneca speaks of voluptates honestae (see e.g. Marc. 3,3), because these enjoyments, as we will see in a moment, are in some way or another connected to a reasonable and moral life, in other words with performing Gr. kathekonta (officia). ${ }^{110}$

Besides, in my view it is not possible to distinguish between the different kinds of good spiritual pleasures sharply. One finds numerous passages in Seneca that concern different forms of spiritual enjoyments of proficientes. In some cases, the verb gaudere is used, in other instances the terms gaudium or voluptas, both in the common meaning of the words.

We experience such pleasure when we lead a simple and honest life; see tranq. 17, 2: At illa quantum habet voluptatis sincera et per se inornata simplicitas. Cp. also epist. 77, 3; 86, 5; 123, 4. We can compare this to the pleasure one experiences when doing a good thing (epist. 102, 18 bene fecisse gaudeo) or the pleasure of performing or receiving benefaction (ben. II, 24, 2; III, 17, 3; IV, 13, 2; VI, 42, 2 voluptas) etcetera. Furthermore, there is also the pleasure Seneca finds in philosophy (epist. 50, 9) or in providing moral education (epist. 6, 4 gaudeo), ${ }^{111}$ and, for instance, the joy the philosopher experiences when he witnesses his "student" Lucilius' moral progression (epist. 5, 1 gaudeo; 20, 1 gaudeo; 34, 1 with voluptas in a comparison ). ${ }^{112}$

Next, there is the pleasure found in having friends (epist. 9, 6 voluptas). In epist. 35, 3 Seneca employs the word gaudium for the pleasure one experiences in an absent friend, and voluptas (specifically viva voluptas!) for the -more physical?-

109 See about epist. 59, 4 in general 4.6.2 infra.

110 See Diogenes LAERTIUS VII, 108: “Appropriate actions are ones which reason dictates our doing, such as honouring parents, brothers and country, spending time with friends." (trans. P. Donini). See also DONINI (1999), p. 730 and ForSCHNER (1981), p. 186.

111 These spiritual voluptates are not the same, but correspond to the Gr. terpsis experienced by the wise man in his own virtuous conduct. See FORSCHNER (1981), p. 140.

112 This voluptas is not the same, but corresponds to the Gr. euphrosyne experienced by the wise man when contemplating the moral behaviour of others. See FORSCHNER (1981), p. 140. 
pleasure of seeing a friend again. Still, the difference I have just pointed out, might be somewhat too far-fetched; in epist. 55, 9 Seneca finds pleasure (voluptas) in his conversation with an absent friend! Besides, we need to keep in mind that amicitia is a virtus (see letter 9). We can compare this to the pleasure one can find in (the wellbeing and success of) one's children (Marc. 10, 4 voluptates and gaudium together; Helv. 14, 3; ben. V, 19, 6).

For that matter, we can also find pleasure in what deceased family members and friends have meant to us in the past, as Seneca points out in expressing comforting thoughts (Marc 24, 4 harum contemplatione virtutum + voluptatis; epist. 63, 4-5 voluptas; 99, 19 gaudium $).{ }^{113}$ In this way, the memory of previous enjoyments is also a pleasure (see ben. III, 4, 1 with thanks to Epicurus!). In Pol. 10, 3 Seneca wrote the following consolation: Itaque in praeteritum tempus animus mittendus est, et quidquid nos umquam delectavit reducendum ac frequenti cogitatione pertractandum est: longior fideliorque est memoria voluptatum quam praesentia.

Besides the aforementioned spiritual pleasures, we can also find innocent (spiritual) pleasure in reading (nat. V, 15, 2) or travelling (Marc. 17, 2), or in solving a riddle or a problem (ben. $\mathrm{V}, 12,2$ ), and even in something funny in the behaviour of a deceased boy: si quos sermones eius, si quos quamvis parvoli iocos cum voluptate audieras, saepius repete (epist. 99, 23). It is part of human nature to find pleasure in play and jest; see tranq. 17, 6: nisi naturalem quandam voluptatem haberet lusus iocusque.

Seneca is certainly not opposed to innocent spiritual pleasures. In tranq. 10, 1 he is even found to say: invenies in quolibet genere vitae oblectamenta et remissiones et voluptates. In this context, he might also be thinking of innocent physical pleasures.

4.6.2. Gaudium s.s. (chara) is, as indicated sub 3.4 supra, reserved for the wise man; it is a by-product of his perfect virtus, it is a joy that arises in the wise man from his awareness of exercising virtue. I concur with W. Görler that it is logical to presume that proficientes who perform kathekonta (and make an effort to achieve virtue $^{114}$ ) also experience a rationally-founded spiritual pleasure that can be appreciated in a positive way. Still, we cannot erase the difference between this kind of "pleasure" and gaudium s.s.

It is not just a matter of logical reasoning that suggests the proficientes experience a rationally-founded spiritual pleasure that can be appreciated in a positive way. There are passages in Seneca, which indicate that such a view was indeed Seneca's own conviction. We can even state that Seneca's expression voluptas honesta is particularly applicable to this kind of pleasure, which arises from the awareness that we have performed kathekonta ourselves or that others have performed kathekonta.

In this respect, I first of all draw attention to epist. 59, 4. Having called the pleasure of reading one of Lucilius' letters "voluptas" in 59, 1, Seneca in epist. 59, 14 pauses to consider the terms voluptas and gaudium, as already stated in the introduction to this study. In 59, 4 Seneca offers the following commentary on his usage of

113 Cp. Borgo (1998), p. 204-205.

114 I add this to what GöRLER (1984) wrote. 
voluptas in 59, 1: Tamen ego non inmerito dixeram cepisse me magnam ex epistula tua voluptatem; quamvis enim ex honesta causa inperitus homo gaudeat, tamen adfectum eius inpotentem et in diversum statim inclinaturum voluptatem voco, opinione falsi boni motam, inmoderatam et inmodicam- "Nevertheless, I was not wrong in saying that I received great 'pleasure' from your letter; but, although the non-wise may derive 'pleasure' from an honourable cause, yet, I call his passion, which is wayward and is likely to take another direction, 'pleasure'; for it is inspired by an erroneous opinion concerning a false good; it exceeds control and is carried to excess." (trans. R.M. Gummere with changes). In other words: in 59, 1, I did not mistakenly use the term voluptas (according to common usage), as the non-wise (inperitus) can also find "pleasure" in something honourable (ex honesta causa). Still, voluptas s.s. is used by myself and by the other Stoics with regards to the adfectus voluptas (whereas gaudium s.s. according to 59, 2, is reserved for the wise man).

In line with W. Görler (who is not mentioned however), but more careful and more precise, B. Inwood (2007) judges - correctly in my view - that in a case such as epist. $123,4{ }^{115}$ we can perhaps speak of a kind of "second-order pleasure" for the proficiens, which is comparable to chara. I first cite the passage in question from Seneca's letter: Aestimari non potest quantam voluptatem capiam ex eo quod lassitudo mea sibi ipsa adquiescit: non unctores, non balineum, non ullum aliud remedium quam temporis quaero. Nam quod labor contraxit quies tollit. Haec qualiscumque cena aditiali iucundior erit. B. Inwood's commentary reads as follows: "Seneca emphasizes the second-order pleasure he takes in being aware of having dispositions of which he approves upon reflection. This is comparable to Epicurean mental pleasures, or, perhaps, to Stoic chara (...)." "116

Following the use of the expressions "first-order-" and "second-order pleasure" in J.M. Rist (1969), ${ }^{117}$ B. Inwood uses "second-order pleasure" here for the proficiens' positive reflection upon the good attitude he has gained over the years. In this respect, I think it is useful and clarifying to refer to another passage from B. Inwood's commentary, which comments on epist. 76, 28-30 (and 76, 27): ${ }^{118}$ "It is irrelevant whether this pleasure is the gaudium of the sage reflecting on a fully virtuous act of self-sacrifice or some lesser form of pleasure open to the progressor who has made an appropriate but not virtuous act of self-sacrifice."

I think that the comment of B. Inwood ad epist. 123, 4 could be added to some of the passages I have cited in 4.5.1 supra (viz. tranq. 17, 2: At illa quantum habet voluptatis sincera et per se inornata simplicitas; epist. 50, 9: Seneca says there is pleasure to be found in philosophizing; 77,$3 ; 86,5 ; 102,18)$. Parallel to the stable gaudium that goes together with the wise man's perfect virtus, the advanced profi-

115 Ad loc, p. 356.

116 In this respect he also refers to epist. 23, 1-8 and 59, 1-4. BorGo (1998), p. 203 fails to make a sharp distinction between the wise man's gaudium and the proficientes' voluptates honestae, which are to a certain extent comparable with the former.

117 P. 38.

118 P. 214. 
ciens enjoys a voluptas honesta when he dwells upon his efforts towards reasonable and moral living.

Seneca's views on this kind of rationally-founded pleasure are very well expressed in epist. 4, 1, where he writes to Lucilius: Persevera ut coepisti et quantum potes propera, quo diutius frui emendato animo et composito possis. Frueris quidem etiam dum emendas, etiam dum componis: alia tamen illa voluptas est quae percipitur ex contemplatione mentis ab omni labe purae et splendidae. In both cases, we have a spiritual voluptas at hand that Seneca appreciates greatly, but the pleasure that one experiences when contemplating a completely pure mind (i.e. gaudium s.s.!), is pleasure of an entirely different order.

Having positively mentioned the fact that Epicurus used to fast at certain days in order to test himself in epist. 18, 9, Seneca goes on to say in 18, 10: In hoc tu victu saturitatem putas esse? Et voluptas est; voluptas autem non illa levis et fugax et subinde reficienda, sed stabilis et certa. Non enim iucunda res est aqua et polenta aut frustum hordeacii panis, sed summa voluptas est posse capere etiam ex his voluptatem et ad id se deduxisse quod eripere nulla fortunae iniquitas possit. In this case, we are not talking about the (first-order) pleasure of satisfying hunger anymore, but about the bigger (spiritual, second-order) pleasure found in becoming independent of Fortune.

I would add the following note to these passages. It is not only logical that the Stoa in general and Seneca in particular would reason the way W. Görler would logically expect, Seneca effectively sees things as such, for instance in epist. 4, 1; 18, 9 and 59,4 . To boot, it is not only a matter of logic. In my view, it is also a crucial aspect of Seneca's philosophical motivation and the way in which he wants to motivate and incite Lucilius and his readers. He does so, partly by holding out to them the prospect of the wise man's gaudium, and partly by talking in a positive way about the voluptas honesta of the proficientes.

4.6.3. However, when it comes to the spiritual pleasure that resides in recalling the memory of past physical pleasures, Seneca does voice serious concerns. Without a doubt he considers this a manifestation of seeking out pleasure. It is typical of De vita beata that Seneca precisely focuses on this kind of "spiritual" pleasure when attacking Epicureanism in vit. 6, 1; Epicureanism and the glorification of voluptas need to be rendered harmless. When his opponent raises the objection that the Epicureans are not only concerned with the body, but also with the enjoyments of the mind, Seneca criticizes in the Epicurean position 1) the role played by the mind as arbiter in the choice of pleasures; 2) the fact that the animus pursues pleasure; 3 ) the fact that the animus finds a special kind of pleasure in the memory of past physical pleasure and the prospect of future sensual enjoyments. For the philosopher it is quite dreadful that people look for pleasure in the wrong things.

Obviously, the pleasure found in another's misfortune is completely rejectable; in such cases, Seneca speaks of voluptas inhumana $(\text { tranq. } 15,5)^{119}$. Equally rejec-

119 In this case, we have what is called in Greek epichairekakia (see index $S V F$ ). See Stobaeus, ecl. II, p. 90, 19 - p. 91, 9W (and LS vol. 1, p. 412). Cp. also Cicero, Tusc. IV, 66 
table is self-satisfaction or deception. In such cases, we are undoubtedly dealing with spiritual pleasure as pathos. In the context of De vita beata this is explicitly discussed in vit. 10, 2. Everyone knows, according to Seneca, that animum... ipsum genera voluptatis prava et multa suggerere. Next, he starts summing up such "pleasures": in primis insolentiam et nimiam aestimationem sui tumoremque elatum super ceteros et amorem rerum suarum caecum et inprovidum et ex minimis ac puerilibus causis exultationem, iam dicacitatem ac superbiam contumeliis gaudentem, desidiam dissolutionemque segnis animi, deliciis fluentis, indormientis sibi. All these are behaviours and attitudes in which the person who puts pleasure first, would find enjoyment.

Elsewhere, still other erroneous spiritual enjoyments are mentioned, for instance the pleasure found in contumelia (const. 17, 4), crudelitas, feritas or saevitia (ira II, 5, 2; III, 18, 4; clem. I, 11, 4; I, 25, 2; II, 4, 2), and ira (ira II, 32, 1).

4.7. However, when Seneca is discussing pleasure in a disapproving way without further specification, he is almost always thinking of physical pleasures, which is obviously first of all (although not exclusively) voluptas as a pathos. ${ }^{120}$ Yet, he will not easily put in a good word for acceptable physical enjoyments either, unless he is talking about frugality and moderation. Seneca does explain in which cases and within which boundaries certain physical pleasure is acceptable, but for the rest he mainly warns against the dangers of the pathos physical pleasure.

4.7.1. Physical pleasure is only acceptable to the extent that nature has attached it to life-preserving actions (e.g. food and drink), or to something that fits with our nature and is preferable (e.g. good health). In such cases, we can speak of pleasure that is in accordance with our nature. Even more, we are actually dealing here with the pleasure that comes naturally with performing kathekonta, actions according to nature, which are necessary for our self-preservation. In other words, such actions have to do with the Stoic concept of oikeiosis (cf. epist. 116, 3 cited above). The pleasure in question is the hêdonê mentioned by Diogenes Laertius in VII, 85-6: this pleasure is an epigennema of the successful actions we perform with the intent of selfpreservation and self-development. In my view, we can refer to this pleasure with the expression voluptas naturalis, which Seneca uses in tranq. (cf. supra 4.2).

However, I repeat that all of this is only valid on condition that we do not pursue this pleasure and respect the boundaries set by nature. Similarly to the acceptable spiritual pleasures that fall outside of gaudium, these acceptable, natural physical pleasures are not really discussed in the attack on voluptas in De vita beata c. 6-16. Moreover, contrary to the acceptable spiritual voluptates, the acceptable physical pleasures are rarely mentioned in a positive way as such outside of vit.

A natural pleasure is, for instance, the pleasure we experience when drinking water to quench our thirst or when eating food to satisfy our hunger. Nature asks for

Not entirely consistent, but not that unusual in philosophical texts is const. 14, 1: quanta voluptate inplendus animus ex alienorum errorum tumultu contemplanti quietem suam!

${ }^{120}$ In epist. 104, 34 Seneca is negative about the indifferent voluptas. In epist. 84, 11 corporis atque animi voluptates are mentioned together with divitiae and ambitus! 
very little, see epist. 4, 10 as cited above. In a context of frugalitas, we read in tranq. 9, 2: Cibus famem domet, potio sitim, libido qua necesse est fluat. ${ }^{121}$

This kind of pleasure is wanted by nature itself so that we would perform lifepreserving actions more swiftly (cf. supra, 4.2.2, regarding epist. 116, 3). Accordingly, only this kind of physical pleasure is acceptable (epist. 102, 28 ${ }^{122}$ )! In this context, Seneca points out in Helv. 13, 3 that libido does not exist voluptatis causa but for the purpose of procreation. For the pleasure attached to procreation, see also ben. III, 31, 1; III, 33, 4 and IV, 8, 1.

Pleasure needs to stay within the boundaries set by nature. As already mentioned, Seneca discusses these boundaries for pleasure very often. For instance, he points out the boundaries of physical pleasure in vit. 20, 5: Edendi mihi erit bibendique finis desideria naturae restinguere, non inplere alvum et exinanire. ${ }^{123}$

4.7.2. Seneca leaves only very little room for physical pleasure. In vit. 8,2 he explains what proper living means in this respect: si corporis dotes et apta naturae conservarimus diligenter et inpavide tamquam in diem data et fugacia, si non subierimus eorum servitutem nec nos aliena possederint, si corpori grata et adventicia eo nobis loco fuerint quo sunt in castris auxilia et armaturae leves - serviant ista, non imperent - ita demum utilia sunt menti.

Apta naturae are without doubt preferable indifferentia or indifferentia according to nature. We must not live in fear because these favours accorded by nature or fortune are not stable goods; we must not be enslaved by them and they need to know their place.

In epist. 92, 33 we read that the person in whom ratio is in charge corporis... ut oneris necessarii non amator sed procurator est. Cp. vit. 3, 3 corporis sui pertinentiumque ad id curiosa non anxie.

Someone who exercises virtus already assigns little weight to pleasure to begin with (vit. 10, 3), and only allots it a subordinate position (vit. 8,2), far beneath virtus (vit. 14, 1). Seneca only tolerates pleasure within certain limits and certain conditions, hence a radical statement like vera voluptas erit voluptatum contemptio (vit. 4, 2).

It is clear that especially in the case of physical pleasure Seneca only begrudgingly allots it this position. Even though he knows that physical pleasure plays a part in man's proper functioning, as we have seen, Seneca still looks at it with mistrust and

${ }^{121} \mathrm{Cp}$. for the translation of the final words: "et réduisons à la satisfaction de nos besoins élémentaires notre vie sexuelle" (Colette Lazam) and "i bisogni fisici si sfoghino nei limiti di natura" (Luigli Castiglioni). For the whole of the cited sentence, compare epist. 8, 5 cibus potio - vestis (see Maria Grazia Cavalca Schiroli ad Sen. tranq. 9, 2). Libido is present in a somewhat similar way in epist. 77, 6, where in the face of death a Stoic points out that life, an endless repetition of cibus, somnus, libido, gets boring in the long run.

122 The text Huic nunc quoque tu quantum potes $s u b<d u c$ te $>$ voluptatique nisi quae*** necessariisque cohaerebit alienus is uncertain, but almost certainly deals with natural and necessary pleasures.

${ }^{123}$ With exinanire Seneca points at the fact that some empty a full stomach in an artificial way in order to be able to stuff themselves a second time. 
contempt (epist. 124, 3). He wants us to live manly (viriliter, ibid.), and asks us whether the stimulation of our senses (titillatio) is something to be proud of (vit. 5, 4 and especially epist. 92, 6-7; cp. also ben. VII, 2, 2). ${ }^{124}$ Physical pleasure serves the belly (venter, vit. 9, 4 and 14, 4), it is connected to the animal side of man (vit. 9, 4; voluptas, bonum pecoris est, epist. 92, 6; cp. epist. 123, 16). Voluptas, so we read in vit. 9,4 , is not hominis bonum. In certain cases, it is plainly turpis, i.e. morally reprehensible (turpe is the opposite of honestum, morally good), and not worthy of man (vit. 7, 1-2; ben. VII, 2, 2). Whereas physical pleasure is an animal thing, virtus on the other hand turns man into an image of the deity (vit. 16, 1). Man, who resides between deity and animal, must strive to get as close as possible to the divine (see e.g. epist. 92, 3 and 27-30; cp. also epist. 59, 14 and 18). ${ }^{125}$

4.8.1. To maximalize the opposition between virtus and voluptas, Seneca, in vit. 12 , opposes the virtuous person, the wise man, to the person who wallows in pleasure. It goes without saying that the sapiens does not pursue pleasure, he does nothing voluptatis causa (vit. 11, 1). Vit. 12, 2 deals with the moderate voluptates the wise man allows. In my opinion, we are dealing with various innocent pleasures here, i.e. voluptates, not the aforementioned gaudium $=\mathrm{Gr}$. chara! I state this with some emphasis, as G. Kuen ad vit. 12, 2 does not at all specify which pleasure is meant here. In my view, my argument is almost beyond any doubt, as can be concluded from several elements from the paragraph in question, for instance the notion that these enjoyments are not in honore with the wise man - "are not held in high esteem", and are received (sine) ullo gaudio percipientium - "without joy on the part of those who experience them".

Besides, in the case of the wise man these enjoyments are radically different from similar enjoyments in the case of he who seeks pleasure: At contra sapientium remissae voluptates et modestae ac paene languidae sunt compressaeque et vix notabiles, ut quae neque accersitae veniant nec, quamvis per se accesserint, in honore sint neque ullo gaudio percipientium exceptae; miscent enim illas et interponunt vitae ut ludum iocumque inter seria (vit. 12, 2; cp. ben. VII, 2, 3-4). The wise man did not pursue the enjoyments mentioned. They fell to his lot as an extra (cp. e.g. the natural pleasure experienced in food and drink) and the wise man does not attach too much importance to them. In his case, the pleasure is in itself not an indication of any passion. $^{126}$

It is crucial that the wise man, and likewise the proficientes who put virtus first, stay in control of their enjoyments: habebimus nihilo minus voluptatem, sed domini eius et temperatores erimus (vit. 14, 1; cp. ira II, 20, 3 - about a "moderate pleasure", modica... voluptas). Time and again, Seneca mentions the moderation and tempering of pleasures. He expresses his admiration for Marcia's deceased son, who had put himself above all physical enjoyments (victorem omnium voluptatium ani-

124 In nat. I, 113 Cicero writes that titillatio corresponds to Gr. gargalismoi sômatos in Epicurus (cp. for Epicurus' usage of this term, e.g., ATHENAEUS XII, 546 ${ }^{\mathrm{e}}$ ).

${ }^{125} \mathrm{Cp}$. CiCERO, fin. II, 40 and II, $109 \mathrm{sq}$.

${ }^{126} \mathrm{Cp}$. accesserint in vit. 12, 2 with accessio in epist. 66, 35 as cited in the above. 
mum, Marc. 23, 3). Hercules and Ulysses, who are moral models in the Stoa, are called contemptores voluptatis in const. $2,1{ }^{127}$

4.8.2. At this point, I would like to draw some attention to a statement by W. Görler. ${ }^{128}$ According to him there is no reason to suppose that the wise man's chara would be a restrained joy. If we interpret Seneca, vit. 12, 2 as we have done, Seneca's passage does not contradict W. Görler. Indeed, Seneca does not speak here of gaudium but of remissae voluptates! Still, I would like to point out that for Seneca the supreme good and gaudium always go hand in hand with tranquillitas. See, for instance, tranq. 2, 4: Ergo quaerimus quomodo animus semper aequali secundoque cursu eat propitiusque sibi sit et sua laetus aspiciat et hoc gaudium non interrumpat, sed placido statu maneat nec attollens se umquam nec deprimens; id tranquillitas erit; ${ }^{129}$ Helv. 5, 1 nec secunda sapientem evehunt, nec adversa demittunt and, on the other hand, epist. 99, 21 inprudentium ut gaudia sic dolores exundavere.

\section{Concluding observations}

5.1.1. When we look back upon what Seneca has to say about voluptas (I leave gaudium s.s., for Seneca the vera voluptas, aside for a minute), several aspects are especially striking:

(1) Seneca combats Epicureanism and opposes the opinion that voluptas is the supreme good. However, he goes even further and calls virtus and voluptas inconvenientia in De vita beata, i.e. things that do not go together!

(2) Seneca fights the pathos voluptas forcefully and with many arguments.

(3) Seneca only accepts physical enjoyments to the extent that they are provided by nature as an epigennema of necessary actions and of a natural state, but, in his view, they are trivial and it is better not to pay too much attention to them.

(4) Seneca highly appreciates many spiritual enjoyments or voluptates honestae, by which he primarily means enjoyments that come with a proper, reasonable and moral life, and the progress one makes en route towards virtue.

That Seneca combats Epicureanism and the pathos voluptas is something one would expect from a Stoic. That he is also reserved about acceptable physical enjoyments and does not advertise them is also understandable for several reasons, which I will enumerate again shortly. With regards to preferably indifferentia in general B. Inwood (1999) ${ }^{130}$ wrote very justly: "The moral agent spends a good part of his time dealing with the preferred things, making decisions and choices among them. The challenge for Stoic moral theory and practice, then, is not to motivate moral

127 RIST (1969), p. 45 and GÖRLER (1984), p. 411 seem to accept that all of the wise man's enjoyments (all of them rationally justified enjoyments) are considered chara by the Stoa. In my view, the Stoa theoretically could indeed call all the wise man's enjoyments chara, yet, as we have seen, Seneca limits gaudium s.s. / chara to the joy that nascitur..ex virtutum conscientia, and uses voluptates for the wise man's various innocent (physical) enjoyments. Cp. supra n. 79.

128 P. 412-413.

129 See also KUEN (1994), p. 171.

130 P. 693. 
agents to pay attention to such things nor even to put a positive value on the preferred things; people will do that on their own. Rather, it is to induce them to do so in the way which will bring them closer to virtue."

In his daily life, the philosopher Seneca appears to have paid attention to innocent and higher forms of spiritual pleasure, smaller and bigger spiritual enjoyments. We get to know his disposition in this respect from many statements in his philosophical works, as well as from his wit, but above all from the special attention he has for gaudium, the true joy.

The fact that in the part of De vita beata that deals with the opposition between virtus and voluptas almost all the attention goes to the negative side of voluptas, is caused by Seneca's aim to polemically oppose voluptas and virtus as sharply as possible. It is quite typical that, against this backdrop, even when it comes to the spiritual enjoyments that fall outside of gaudium, Seneca mainly discusses the spiritual enjoyments that are not commendable. In his in-depth plea for virtus as the supreme good, the acceptable, innocent spiritual and physical enjoyments almost automatically disappear out of the limelight. On the other hand, there is also the general fact that Seneca the Stoic tends to avoid, as it were, presenting physical pleasures in a positive way.

Over the course of this study we have advanced several reasons why there is not more room for voluptas, and especially for physical enjoyments, in the Stoa.

The crucial issue is that in principle the Stoa connects human happiness exclusively with what is specifically human, the animus. Only reasonableness and morality, virtus, can make us completely happy and produce a happiness that does not make us dependent on Fortuna. Indeed, being as independent of Fortune as possible (i.e. having as much autarkia as possible) was an important goal of all philosophers in Greco-Roman Antiquity.

Man has his place in between animal and god. Indulging in physical pleasures puts him closer to the animal side, whereas he should precisely struggle to get closer to the divine.

The Stoics do not wish to jeopardize the quest for virtus and choose to keep themselves at a safe distance from pleasures that as unbridled passions can sweep us away. Being moderate when it comes to pleasures, once one has admitted them, is very difficult. Therefore, the negative, dangerous consequences of passionate pleasure are dealt with in great detail.

Voluptas modica can be, or is, as Seneca states expressly in tranq., necessary for our balance, but virtus always needs to be in charge and one must never act voluptatis causa.

5.1.2. Enjoyments (voluptates) are, according to Seneca, not something to be proud of (in contrast with virtus); see e.g. vit. 5, 4 on titillari. This is something he may state from his point of view, yet enjoyments are a necessary part of life, just like food and drink ; the only thing that matters is to deal with them in a proper way.

Another observation concerns the fact that pleasure is not only natural, as Seneca writes himself (e.g. tranq. 17, 6), but also useful, an aspect Seneca deals with 
in epist. 116, 3. In this paragraph, the philosopher draws attention to the fact that nature has added pleasure to a number of necessary actions so that we should perform these life-preserving actions more swiftly. In this respect, we can also refer to Seneca's Consolatio ad Marciam, where he urges Marcia to take comfort in the spiritual pleasure offered by the cherished memories of her deceased son, and to be sure to enjoy her other children. These are only small remarks, but they could be the philosophical basis of a slightly more positive attitude towards pleasure, including physical enjoyments.

5.2. In Stoicism the ratio dominates everything. Not only is ratio the centre of gravity for everything that is happiness in Stoicism, but ratio also decides what is the supreme good. ${ }^{131}$ In Epicureanism, by contrast, the senses determine what is the supreme good, and the senses are the centre of gravity for everything that is happiness and pleasure. However, we need to remember that for Epicurus a pleasant life is the result of rational choices.

Yet, what we have said about the position of ratio in Stoicism does not mean that the Stoic Seneca leaves no room for pleasures or joy. These issues do play a significant part. Still, in saying so I do not refer to the undeniable fact that Seneca very regularly ranted against pursuing physical pleasure and uses many arguments to warn against the negative consequences of this kind of pleasure. Within Stoic theory as viewed by Seneca, there is indeed some room for natural, moderate pleasures, although chiefly spiritual enjoyments. Seneca is extremely suspicious of physical pleasure. He tolerates natural physical pleasures, but not much more. Yet, as a person with common sense Seneca also has attention for the necessity to relieve the heavy aspects of life with lighter and more enjoyable things. Besides, at times he can be quite witty in his philosophical writings.

Most pleasures that Seneca deems fit to mention are actually spiritual enjoyments that in some way or another are connected to a reasonable and moral life. Yet, above all common pleasures of life towers the wise man's gaudium, the perfect and stable joy that comes directly from the awareness of perfect reasonable and moral conduct. $^{132}$

KU Leuven

Eikendreef 11

Willy EVENEPOEL

B-3061 Leefdaal (Bertem)

willy.evenepoel@skynet.be

131 Cp. Inwood (2007) ad Sen. epist. 123, 2-6.

132 In a sequel to this study, I shall offer some additional observations (1) on Seneca's Stoic frame of reference and (2) on the summum bonum and other bona. 


\section{Editions}

SENECA, dial.: L.D. ReYNOLDS, Oxford, 1977; epist.: L.D. REYNOLDS, Oxford, 1965; ben.: F. PrÉchaC, Paris, 1926-1927 ; clem.: F.-R. Chaumartin, Paris, 2005; nat.: H.M. Hine, Stutgardiae et Lipsiae, 1996.

EPICURUS: R. NiCKEL, Düsseldorf-Zürich, 2003; $S V F=$ H. VON ARNiM - M. AdLER (eds), Stoicorum Veterum Fragmenta, 4 vol., Leipzig, 1903-1929; LS = A.A. LONG - D. SEDLEY (eds), The Hellenistic Philosophers, 2 vol., Cambridge, 1987; CicEro: Tusc: O. Gigon, Darmstadt, 1976; fin.: O. GigON - L. Straume-Zimmermann, München-Zürich, 1988.

\section{Books of reference, commentaries, lexica and studies}

Algra (1999) = Algra K. et al. (eds), The Cambridge History of Hellenistic Philosophy, Cambridge, 1999.

Borgo (1998) = Borgo A., Lessico morale di Seneca, Napoli, 1998.

Brennan (2003) = Brennan T., "Stoic Moral Psychology," in Inwood (2003), p. 257-294.

BRUnSChWig - Sedley (2003) = Brunschwig J. - SEDley D., "Hellenistic Philosophy," in SEDLEY (2003), p. 151-183.

Busa - Zampolli (1975) = Busa R. - ZAmpolli A., Concordantiae Senecanae, 2 vol., Hildesheim-New-York, 1975.

DONINI (1999) : cf. INWOOD - DONINI (1999).

FORSCHNER (1981) = FORSCHNER M., Die stoische Ethik (...), Stuttgart, 1981.

GÖRLER (1984) = GÖRLER W., "'Pflicht' und 'Lust' in der Ethik der alten Stoa," in Actes du VII Congrès de la Fédération internationale des Études Classiques, Budapest, 1984, p. $397-$ 413.

Gosling - TAYlor (1982) = GosLing J.C.B. - TAYLOR C.C.W., The Greeks on Pleasure, Oxford, 1982.

Grimal (1969) = Grimal P., L. Annaei Senecae De vita beata. Sénèque, Sur le bonheur. Édition, introduction et commentaire, Paris, 1969.

Grimal (1978) = Grimal P., Sénèque ou la conscience de l'Empire, Paris, 1978.

HAYNES (1962) = HAYNES R.P., "The Theory of Pleasure of the Old Stoa," AJPh 83 (1962), p. $412-419$.

INWOOD - DONINI (1999) = INWOOD B. - Donini P., "Stoic Ethics," in AlgRA (1999), p. 675738.

Inwood (2003) = Inwood B. (ed.), The Cambridge Companion to the Stoics, Cambridge, 2003. Inwood (2007) = Inwood B., Seneca: Selected Philosophical Letters, Oxford, 2007.

KILB (1939) = KILB G., Ethische Grundbegriffe der alten Stoa und ihre Übertragung durch Cicero im dritten Buch De finibus bonorum et malorum, Freiburg im Breisgau, 1939.

Kuen (1994) = Kuen G., Die Philosophie als 'dux vitae'. Die Verknüpfung von Gehalt, Intention und Darstellungsweise im philosophischen Werk Senecas, am Beispiel des Dialogs "De vita beata" - Einleitung, Wortkommentar und systematische Darstellung - , Heidelberg, 1994.

MaUrach (2000) = MaURACH G., Seneca. Leben und Werk, Darmstadt, 2000, 3., durchgesehene Auflage.

Motто (1970) = Mотто A.L., Seneca Sourcebook (...), Amsterdam, 1970.

Мотто (2001) = Мотто A.L., "Seneca on Pleasure," in Мотто A.L., Further Essays on Seneca, Frankfurt e.a., 2001, p. 17-31. 
NiKolsky (2001) = NiKolsky B., "Epicurus on Pleasure," Phronesis 46 (2001), p. 440-465 Powell (1995) = Powell J.G.F., Cicero the Philosopher. Twelve Papers, Oxford, 1995. RIST (1969) = RIST J.M., Stoic Philosophy, Cambridge, 1969.

Sedley (2003) = SEDley D. (ed.), The Cambridge Companion to Greek and Roman Philosophy, Cambridge, 2003.

Stokes (1995) = Stokes M.C., "Cicero on Epicurean Pleasures," in Powell (1995), p. 145170. 